\title{
Central Facilities Area Sewage Lagoon Evaluation
}

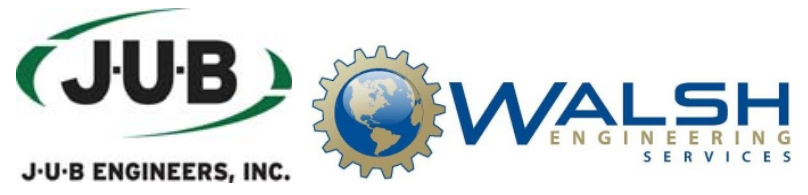

December 2014

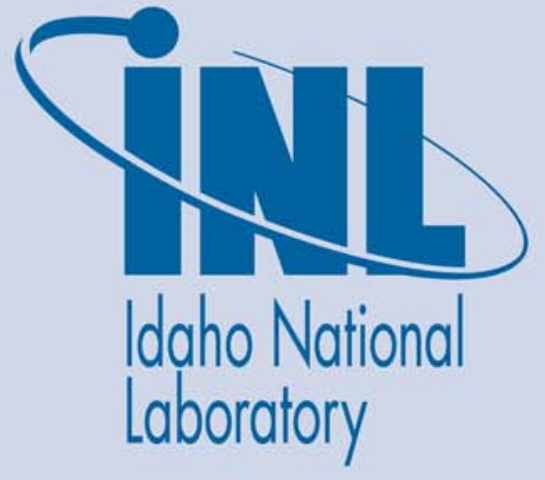

The INL is a U.S. Department of Energy National Laboratory operated by Battelle Energy Alliance 


\section{DISCLAIMER}

This information was prepared as an account of work sponsored by an agency of the U.S. Government. Neither the U.S. Government nor any agency thereof, nor any of their employees, makes any warranty, expressed or implied, or assumes any legal liability or responsibility for the accuracy, completeness, or usefulness, of any information, apparatus, product, or process disclosed, or represents that its use would not infringe privately owned rights. References herein to any specific commercial product, process, or service by trade name, trade mark, manufacturer, or otherwise, does not necessarily constitute or imply its endorsement, recommendation, or favoring by the U.S. Government or any agency thereof. The views and opinions of authors expressed herein do not necessarily state or reflect those of the U.S. Government or any agency thereof. 


\section{Central Facilities Area Sewage Lagoon Evaluation}

J-U-B ENGINEERS, Inc.

275 South $5^{\text {th }}$ Ave, Suite 220

Pocatello, ID 83201
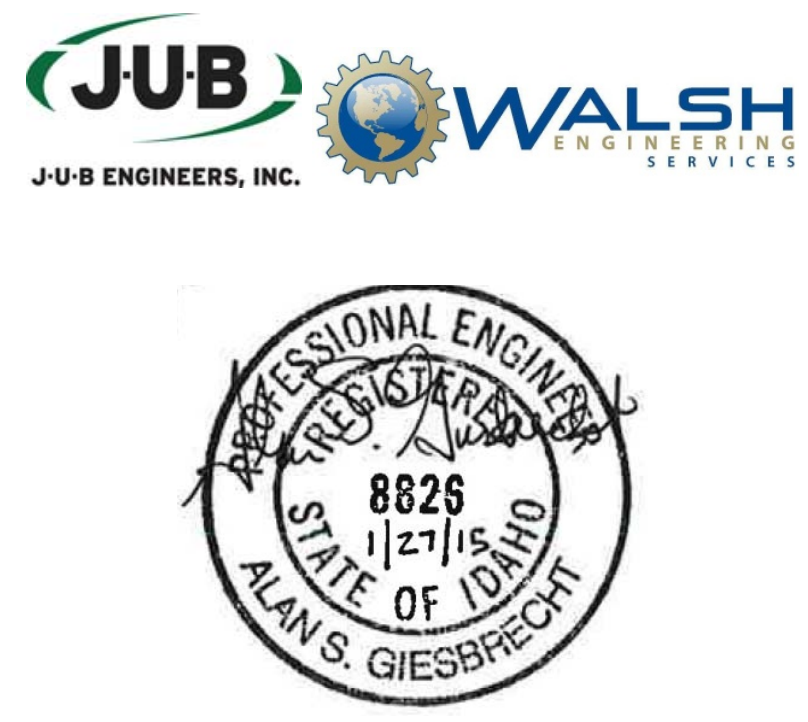

December 2014

Idaho National Laboratory Sustainable INL Program Idaho Falls, Idaho 83415

http://www.inl.gov

Prepared for the

U.S. Department of Energy Office of Nuclear Energy Under DOE Idaho Operations Office Contract DE-AC07-05ID14517 




\section{EXECUTIVE SUMMARY}

The Central Facilities Area (CFA) located in Butte County, Idaho at Idaho National Laboratory (INL) has an existing wastewater system to collect and treat sanitary wastewater and non-contact cooling water from the facility. The existing treatment facility consists of three cells: Cell 1 has a surface area of 1.7 acres, Cell 2 has a surface area of 10.3 acres, and Cell 3 has a surface area of 0.5 acres. If flows exceed the evaporative capacity of the cells, wastewater is discharged to a 73.5-acre land application site that utilizes a center-pivot irrigation sprinkler system.

As flows at the CFA have decreased in recent years, the amount of wastewater discharged to the land application site has decreased from 13.64 million gallons (MG) in 2004 to zero discharge in 2012 and 2013. In addition to the decreasing need for land application, significant amounts of supplemental water have been added to the system (e.g., approximately 7.7 MG in 2013) to maintain a water level and prevent the clay soil liners in the cells from drying and cracking.

INL is concerned that the sewage lagoons and land application site may be oversized for current and future flows. A further concern is the sustainability of the large volumes of supplemental water, which are added to the system to maintain minimum water levels in the lagoons. Therefore, a study was initiated and completed by J-U-B ENGINEERS, Inc. (J-U-B) in December 2013 to evaluate the system capacity, operational practices, and potential improvement alternatives.

In the December 2013 study, a water balance analysis was performed for both "wet" and "dry" conditions. The results of this analysis showed that the lagoons are not oversized and discharge to the land application system with no supplemental water addition should be needed each year to maintain an annual water balance. However, since the results of this analysis did not match recent operations and observations, the impacts of two key variables were investigated further: seepage rates and influent flow rates.

First, a sensitivity analysis was conducted for various seepage rates. The model used the assumed seepage rates obtained from a lagoon seepage rate study that was completed in 2006 . The analysis showed that a small change in the seepage rate can have a significant impact on the water balance of the facility.

Second, a sensitivity analysis was also conducted for the influent flow rate. It was reported by the facility operator that there was uncertainty as to the accuracy of the influent flow data as measured and recorded by the flow meter. The analysis showed that the results of the water balance would change significantly if the influent flow data were not accurate.

In July 2013, the influent flow meter was cleaned, serviced, and recoupled to the pressure main. Since then, new data collected up through October 2014 indicate that flow measurements after the flow meter work average approximately $13 \%$ lower.

In August and September of 2014, an updated seepage rate test was performed by J-U-B. The updated seepage testing shows that the seepage rate has increased in Cell 3 by nearly an order of magnitude since the last seepage rate study conducted in 2006, whereas the seepage rates in Cells 1 and 2 have remained about the same.

The purpose of this current study is to update the analysis and conclusions of the December 2013 study. In this current study, the new seepage rate and influent flow rate data have been used to update the calculations, model, and analysis. 
Based on conversations with BEA staff, this current study assumes that the average monthly flow for the most recent 3 years, October 2010 through September 2014, excluding any supplemental water, will be representative of current and future flows. Data from the influent lift station flow meter for this period of time indicates:

- Sanitary wastewater and non-contact cooling water flow

- $\quad$ Average daily $=35,400$ gallons per day $(\mathrm{gpd})$

- $\quad$ Average annual $=12,900,000$ gallons per year

However, it should be noted that BEA staff feels that the influent flow rate measured and recorded by the influent flow meter are substantially higher than actual given the known uses and activities within the CFA complex, especially when compared to literature values of typical average daily flows per worker. Additional investigation and/or monitoring are outside the scope of this study but are recommended. If it is determined that the influent flow data are not representative of actual flows discharged to the lagoons, the water balance model and observations discussed later in this study should be updated.

Needs and deficiencies of the existing system were identified based on the results of the water balance analyses and discussions with operations personnel. In total, eight key elements were identified:

1. Addition of Supplemental Water. One of the primary concerns is the large volume of supplemental water that has been added to the lagoon system in recent times to maintain a minimum water level in the lagoons. Since the control of seepage from the lagoons relies on the integrity of the clay liners, a water cap must be maintained in the lagoons to prevent drying and cracking. The addition of supplemental water should be continued as needed to maintain the water cap until influent flows increase to maintain the water cap or modifications are made to the lagoons to address the problem.

2. Seepage Testing. A recent seepage test for the lagoons was completed in August and September 2014. Cells 1 and 2 passed the seepage test, but Cell 3 failed. Therefore, action must be taken to prevent excessive seeping from Cell 3. In accordance with Idaho Department of Environmental Quality (IDEQ) Rules (IDAPA 58-01-16), the lagoons will require testing again if a change of condition to the liner occurs (e.g., the liner is replaced) and also at a frequency of every 10 years.

3. Influent Flow Monitoring. As discussed previously, the accuracy of the influent flow measurements have been questioned and the values seem unreasonably high. Therefore, further investigation is recommended.

4. Influent Lift Station. Facility operators have reported that the pump guide rail system in the influent lift station appears to be deteriorating and will likely need to be replaced within approximately 5 years. The condition of the guide rail system and other components of the influent lift station should be monitored and replaced when their conditions warrant replacement.

5. Collection System. The STP operators report that the collection system consists of a combination of concrete pipe and PVC pipe and is in fairly good condition with no known deficiencies. The collection system should continue to be cleaned and maintained in accordance with the established maintenance schedule.

6. Land Application System. Facility operators have reported that the irrigation pump, pivot, and other components of the land application system are in good condition and operate as intended. Although the land application system has not been used in recent years, the system and the associated wastewater reuse permit should be maintained until it can be confirmed that reuse will no longer be required for future flows. The current Wastewater Reuse Permit from DEQ will expire on March 16, 2015. Unless it has been determined that the land application system is no longer needed, the permit should be renewed. 
7. Transfer Structures. Facility operators have reported that the weirs and gate valves located in the transfer structures between the lagoons appear to be aging and showing signs of wear and tear. They have estimated that the components inside the transfer structures will likely need to be replaced within approximately 10 years. The weirs and valves should continue to be serviced and maintained in accordance with manufacturer's recommendations to maximize the remaining service life.

8. Fencing and Signage. IDEQ requires lagoons to be fenced to prevent livestock entering and to discourage trespassing. Since only the west and south sides of the lagoons are fenced, it is recommended that additional fencing be installed to meet this IDEQ requirement. IDEQ also requires signs to be installed around the lagoons and land application site to signify their uses. It is recommended that operators verify that the existing signage meets the IDEQ requirements.

In this study, a number of alternatives were considered to address two primary concerns:

- Eliminate or minimize the need for supplemental water as this practice is in conflict with the Site's sustainability goals

- Achieve compliance with DEQ's allowable seepage limit for Cell 3.

For these reasons, the "do nothing" Alternative 1 is not recommended, especially as it would not address the failed liner in Cell 3.

Four other alternatives were briefly evaluated in this study with the following conclusions:

- Alternative 2 - Re-Line Cell 3 Only. Depending on weather conditions, either reuse or supplemental water would still be required.

- Alternative 3 - Re-Line All Cells. Reuse would be required, but supplemental water would not be required as the installation of a high-density polyethylene (HDPE) lining system would not require maintenance of a minimum water level.

- Alternative 4 - Abandon Cell 3. Depending on weather conditions, both reuse and supplemental water would still be required.

- Alternative 5-Abandon Cell 3; Reconfigure Cell 2. Reconfiguring Cell 2 in addition to abandoning Cell 3 would allow the size of Cell 2 to be reduced to save cost and divided into two cells for storage redundancy. Because of the earthwork required, the existing clay liner would likely be disturbed and replacing it with a new geosynthetic lining system would be recommended. This would eliminate the need for supplemental water but require continued discharge to reuse.

Ultimate selection of the preferred alternative should take into account a detailed comparison of the available alternatives with consideration of life cycle cost, regulatory requirements, schedule, implementability, operation and maintenance requirements, and day-to-day reliability.

Depending on whether the improvements would be considered a "material modification," implementation of an alternative may require a number of submittals to IDEQ including:

- A facility planning study

- A preliminary engineering report

- Construction drawings and specifications

- Record drawings and specifications

- Operation and maintenance manual. 


\section{CONTENTS}

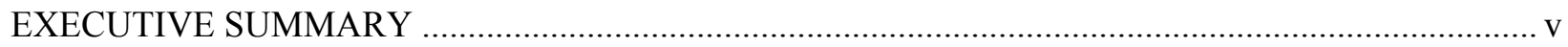

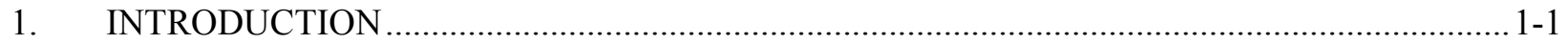

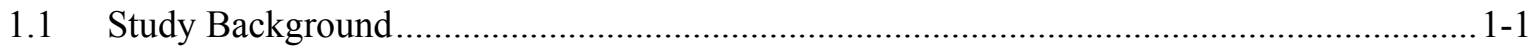

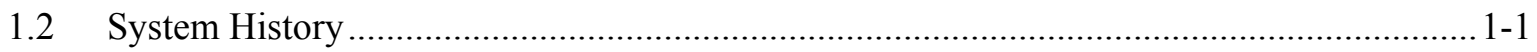

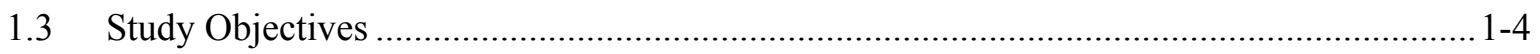

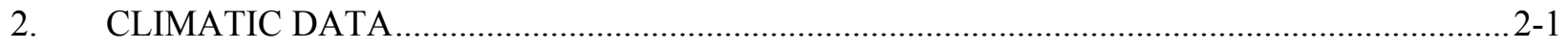

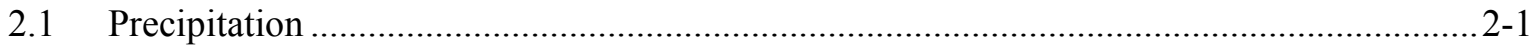

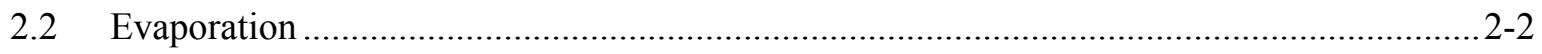

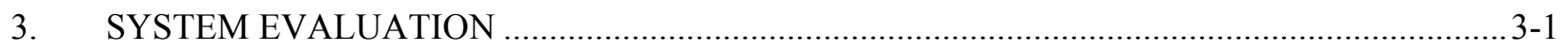

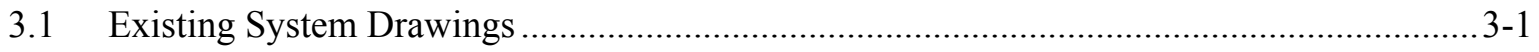

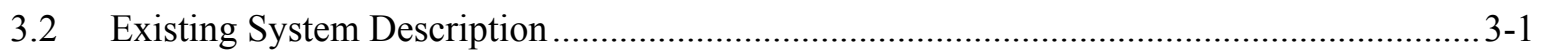

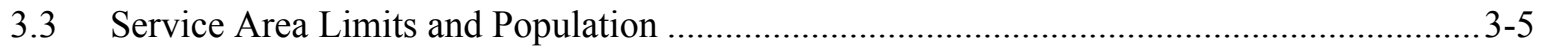

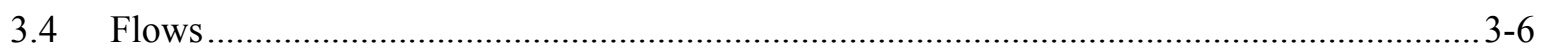

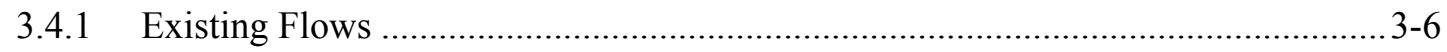

3.4.2 Flow Meter Correction Factor......................................................................... 3-8

3.4.3 Input Flow Data for the Year 2013 Comparison Model ......................................... 3-9

3.4.4 Input Flow Data for the "Working”" Water Balance Model ..................................... 3-9

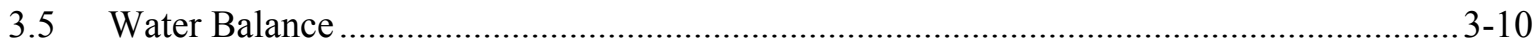

3.5.1 Updated Comparison Model for 2013 …............................................................... 3-10

3.5.2 "Working" Model for Existing Conditions ............................................................. 3-12

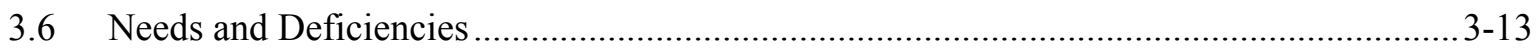

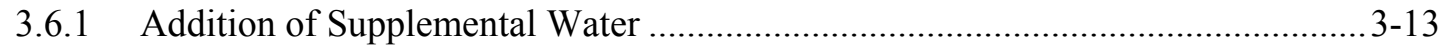

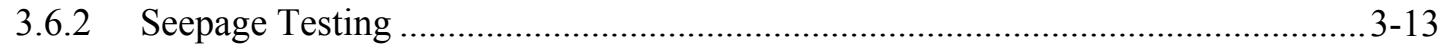

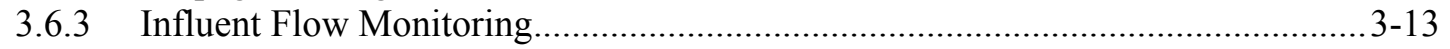

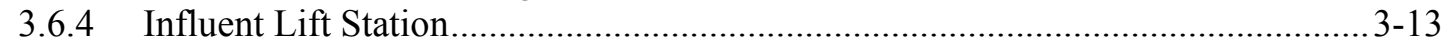

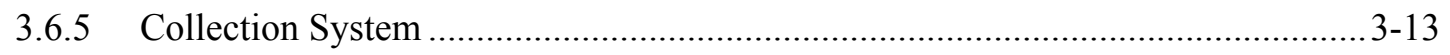

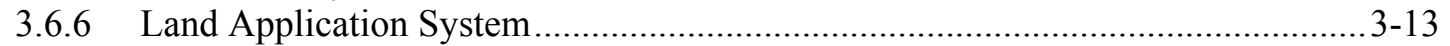

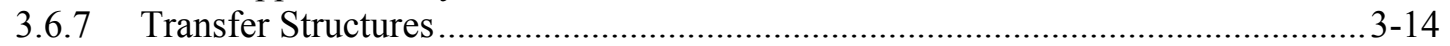

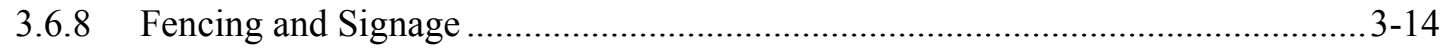

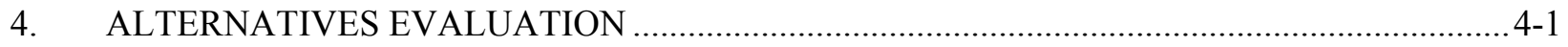

4.1 Screening of Alternatives for Further Evaluation ...................................................... 4-1

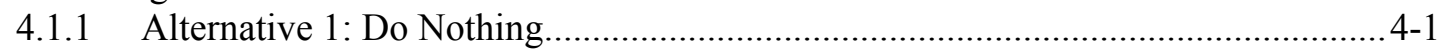

4.1.2 Alternative 2: Re-Line Cell 3 Only ............................................................... 4

4.1.3 Alternative 3: Re-Line All Cells ............................................................................ 4-2

4.1.4 Alternative 4: Abandon Cell 3 ............................................................................. 4-3

4.1.5 Alternative 5: Abandon Cell 3 and Reconfigure Cell 2 ........................................ 4-3

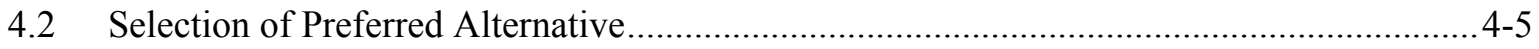

4.2.1 Engineer's Opinions of Probable Cost................................................................... 4-5

4.2.2 Comparison of Alternatives .............................................................................. $4-5$ 
5. IMPLEMENTATION OF PREFERRED ALTERNATIVE .................................................... $5-1$

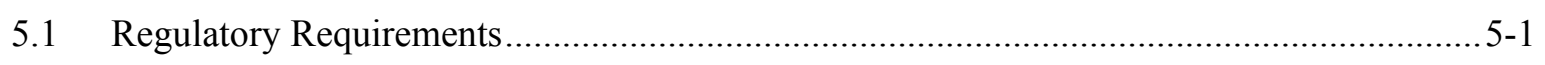

5.2 Summary of Implementation Steps ..................................................................... $5-1$

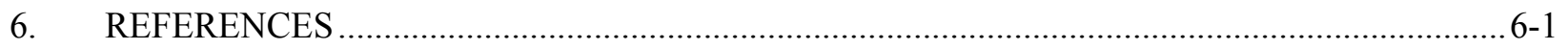

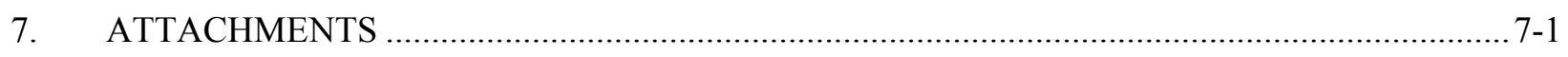

Attachment A Record Drawings for the CFA STP ….......................................................... 1

FIGURES

Figure 1. Area map showing the location of the STP at CFA......................................................... 1-2

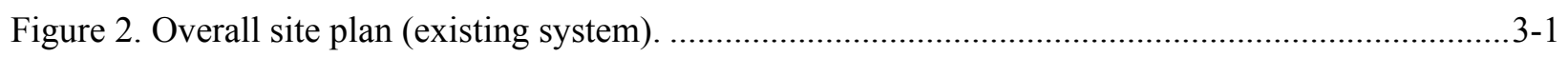

Figure 3. Photo of existing lagoons (Cell 1 in the forefront, Cell 2 behind).........................................3-2

Figure 4. Photo of existing lagoons (Cell 3 in the forefront, Cell 2 behind)..........................................3-3

Figure 5. Photo of existing Transfer Structure 1 between Cells 1 and 2 ...............................................

Figure 6. Photo of existing Transfer Structure 2 between Cells 2 and 3...............................................

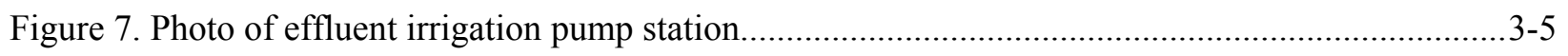

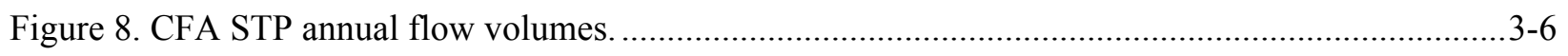

Figure 9. CFA STP monthly influent flow volumes. ..........................................................................

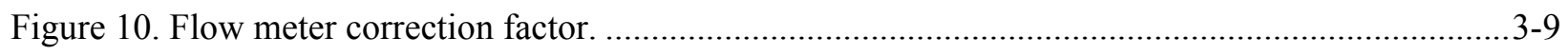

Figure 11. Water balance - updated comparison model, Year 2013 .................................................3-11

Figure 12. Water balance -"wet" year and "dry" year scenarios..........................................................

TABLES

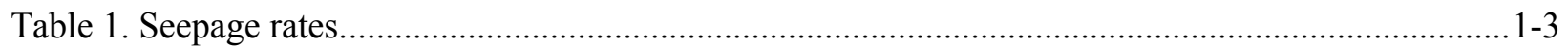

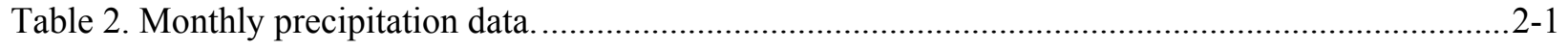

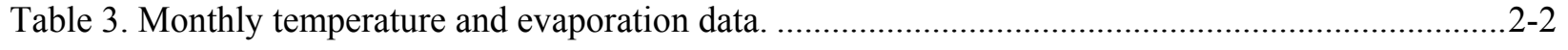

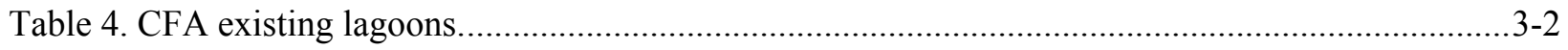




\section{Central Facilities Area Sewage Lagoon Evaluation \\ 1. INTRODUCTION}

\subsection{Study Background}

The Central Facilities Area (CFA) located in Butte County, Idaho at Idaho National Laboratory (INL) has an existing wastewater system to collect and treat sanitary wastewater and non-contact cooling water from the facility. INL is concerned that the sewage lagoons and land application site, which are part of the wastewater system, may be oversized for current and future flows. Also, there is concern about the sustainability of the large volume of supplemental water that is added to the system according to current operational practices. Therefore, this study was initiated to evaluate the system capacity, operational practices, and potential improvement alternatives.

CFA is operated for the United States Department of Energy by Battelle Energy Alliance, LLC (BEA). Walsh Engineering Services, PC, is contracted by BEA to provide facility engineering services for CFA. J-U-B ENGINEERS, Inc. (J-U-B) has been subcontracted by Walsh Engineering Service, PC, to develop this evaluation study.

\subsection{System History}

Prior to 1995, sanitary wastewater from CFA was collected and treated at a mechanical wastewater treatment plant, which consisted of a digester and trickling filter. Deterioration of this wastewater treatment plant led to its replacement.

The new Sewage Treatment Plant (STP) was constructed in 1994 and put into service on February 6, 1995. The STP consists of:

- 1.7-acre partially mixed/aerated lagoon (Cell 1)

- 10.3-acre non-mixed/aerated facultative lagoon (Cell 2)

- $\quad$ 0.5-acre non-mixed/aerated polishing pond (Cell 3)

- 73.5 acre wastewater land application area consisting of desert steppe and crested wheatgrass vegetative communities

- Computerized center-pivot, sprinkler irrigation system.

A 350 gallon per minute (gpm) pump moves wastewater from the lagoons to the center-pivot sprinkler system, which irrigates the land application area at low pressures (about 30 pounds per square inch [psi]).

The CFA STP is managed and operated by the Facilities and Site Services (F\&SS) organization located at CFA.

Figure 1., taken from a previous annual wastewater reuse report, shows the location and layout of the STP at CFA. 


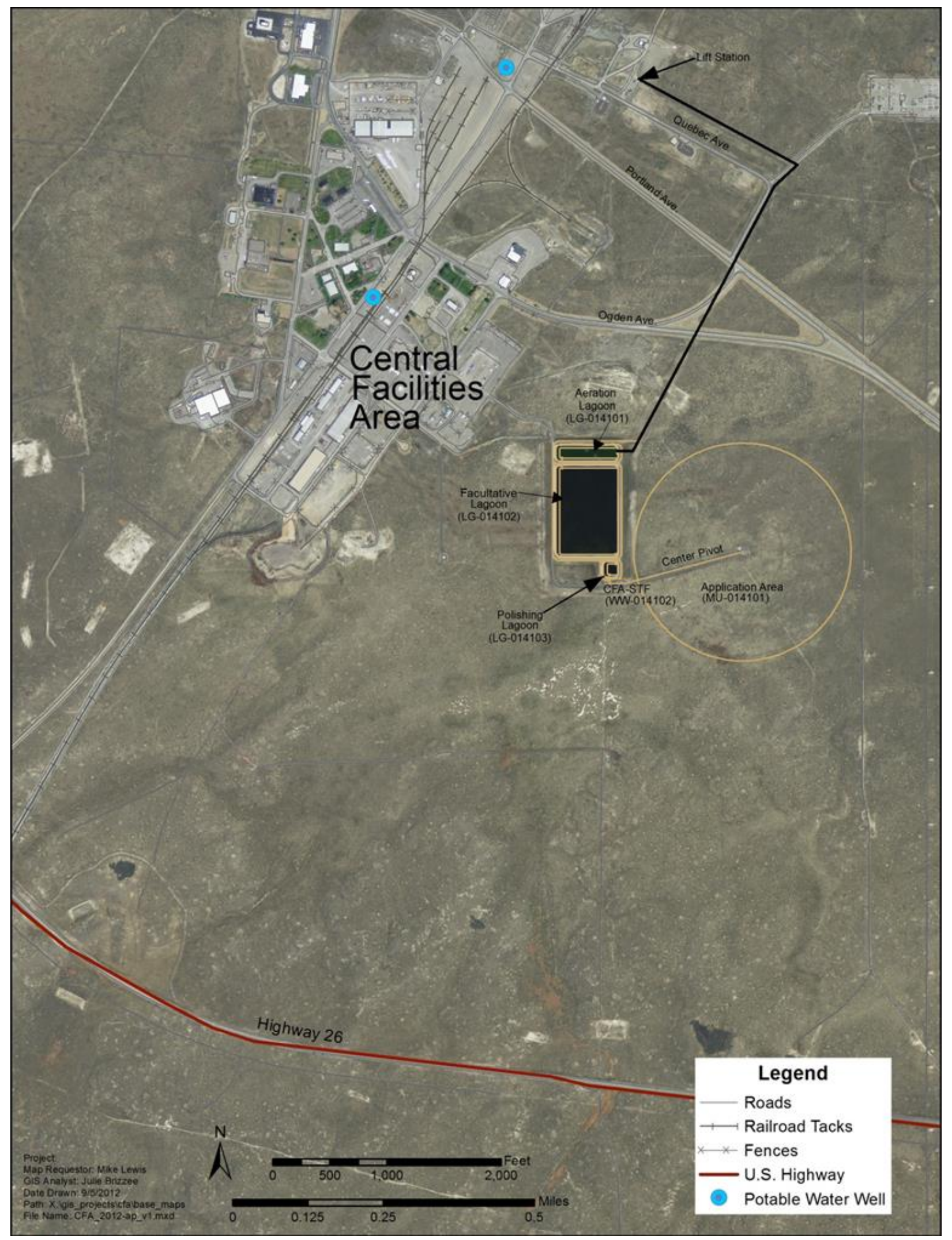

Figure 1. Area map showing the location of the STP at CFA. 
Because clay material cracks when it dries out, lagoons that rely on a clay liner to prevent seepage are typically operated to maintain a minimum depth of water at all times. For this reason and because of the presence of the clay liner material in the CFA lagoons, F\&SS staff operate the system to continuously maintain a minimum depth of water in all three lagoons. In recent years, this has required the addition of large amounts of supplemental water in the summer months when evaporation rates are peaking. The supplemental water is added within the collection system upstream of the influent lift station.

A study was initiated and completed in December 2013 to evaluate the system capacity, operational practices, and potential improvement alternatives, as warranted. In this study, a water balance analysis was performed for both "wet" and "dry" conditions. The results of this analysis showed that the lagoons are not oversized and discharge to the land application system with no supplemental water addition should be needed each year to maintain an annual water balance. However, since the results of this analysis did not match recent operations and observations, the impacts of two key variables were investigated further: seepage rates and influent flow rates.

First, a sensitivity analysis was conducted for various seepage rates. The model used the assumed seepage rates obtained from a lagoon seepage rate study that was completed in 2006 and shown below in Table 1. The analysis showed that a small change in the seepage rate can have a significant impact on the water balance of the facility.

Second, a sensitivity analysis was also conducted for the influent flow rate. It was reported by the facility operator that there was uncertainty as to the accuracy of the influent flow data as measured and recorded by the flow meter. The analysis showed that the results of the water balance would change significantly if the influent flow data were not accurate.

In July 2013, the influent flow meter was cleaned, serviced, and recoupled to the pressure main. Since then, new data collected up through October 2014 indicate that flow measurements after the flow meter work average approximately $13 \%$ lower.

In August and September 2014, an updated seepage rate test was performed by J-U-B. The seepage test results are shown below in Table 1.The updated seepage testing shows that the seepage rate has increased in Cell 3 by nearly an order of magnitude since the last seepage rate study conducted in 2006, whereas the seepage rates in Cells 1 and 2 have remained about the same. Cell 3 exceeded the maximum allowable seepage rate of 0.25 in/day as established in IDAPA 58.01.16.

Table 1. Seepage rates.

\begin{tabular}{|c|c|c|}
\hline Lagoon & $\begin{array}{c}\text { 2006 Seepage Rates } \\
\text { (in/day) }\end{array}$ & $\begin{array}{c}\text { 2014 Seepage Rates } \\
\text { (in/day) }\end{array}$ \\
\hline Cell 1 & 0.082 & 0.083 \\
\hline Cell 2 & 0.046 & 0.055 \\
\hline Cell 3 & 0.054 & $0.455(\geq 0.25)$ \\
\hline
\end{tabular}

It should be noted that operators were not able to add supplement water at a sufficient rate to fill Cells 2 and 3 to their maximum water level of 8 feet prior to the seepage testing. Therefore, because the maximum operating level cannot exceed the level at the time of the test, future operation of Cell 2 is limited to 5.5 feet of depth and Cell 3 to 4.75 feet.

The purpose of this current study is to update the analysis and conclusions of the December 2013 study. In this current study, the new seepage rate and influent flow rate data have been used to update the calculations, model, and analysis. 


\subsection{Study Objectives}

In general, the objectives for this study include the following:

- Describe the climatic conditions relevant to assess the capacity of the lagoons.

- Calculate flows and a water balance for the system for existing and anticipated future conditions.

- Assess the capacity of the STP.

- Identify general needs and deficiencies.

- Identify operational changes to reduce the volume of supplemental water added to the system.

- Preliminarily screen and evaluate alternatives needed to address the needs and deficiencies.

- Describe key issues to consider for selection and implementation of the preferred alternative.

This study is intended to be a cursory assessment and tool to assist with long-term decision making. If a improvements are implemented that are considered a "material modification" to the facility, the preparation of additional documents may be needed, including those required to meet IDEQ requirements such as a facilities plan, preliminary engineering report, detailed plans and specifications for construction, and an operation and maintenance manual. 


\section{CLIMATIC DATA}

\subsection{Precipitation}

Precipitation data was obtained from the Western Regional Climate Center (WRCC). Approximately 59 years of monthly precipitation data for the CFA for the period between April 1954 and March 2013 were analyzed to determine the annual precipitation value that corresponded to both the 10-year high and 10 -year low precipitation years as well as the average precipitation over this period. The 10-year high precipitation value is considered a reasonable value to use in analyzing the capacity of the lagoon system during a "wet" year, whereas the 10-year low value is reasonable for a "dry" year.

For example, the 10-year high is the highest amount of annual precipitation that would statistically occur every 10 years. The annual precipitation amount was then allocated to each month proportionally to the average monthly precipitation. The resulting monthly 10-year high and low-precipitation values are summarized in Table 2 .

For comparison, in this 59-year period, the median annual precipitation was 8.67 inches with a high of 14.4 inches and a low of 4.42 inches. In 2009, which was considered a relatively wet year, the annual precipitation was 10.4 inches (the thirteenth wettest year in the past 59 years). In 2013, the annual precipitation was 3.04 inches, which is significantly lower even than the 10 -year low precipitation values indicating 2013 was a very dry year.

Later in this study, the results of the water balance model were compared with actual data from Year 2013. Thus, precipitation data for 2013 is included in the table below.

Table 2. Monthly precipitation data.

\begin{tabular}{|l|c|c|c|c|}
\hline \multicolumn{1}{|c|}{ Month } & $\begin{array}{c}\text { Average } \\
\text { Precipitation } \\
\text { (inches) }\end{array}$ & $\begin{array}{c}\text { 10-Year High } \\
\text { Precipitation } \\
\text { (inches) }\end{array}$ & $\begin{array}{c}\text { 10-Year Low } \\
\text { Precipitation } \\
\text { (inches) }\end{array}$ & $\begin{array}{c}\text { 2013 Total } \\
\text { Precipitation } \\
\text { (inches) }\end{array}$ \\
\hline January & 0.7 & 0.94 & 0.47 & 0.49 \\
\hline February & 0.58 & 0.78 & 0.39 & 0.01 \\
\hline March & 0.61 & 0.82 & 0.41 & 0.23 \\
\hline April & 0.83 & 1.11 & 0.56 & 0.1 \\
\hline May & 1.22 & 1.64 & 0.82 & 0.43 \\
\hline June & 1.17 & 1.57 & 0.78 & 0.17 \\
\hline July & 0.49 & 0.66 & 0.33 & 0.5 \\
\hline August & 0.47 & 0.63 & 0.31 & 0.0 \\
\hline September & 0.65 & 0.87 & 0.44 & 0.34 \\
\hline October & 0.58 & 0.78 & 0.39 & 0.52 \\
\hline November & 0.63 & 0.84 & 0.42 & 0.13 \\
\hline December & 0.74 & 0.99 & 0.50 & 0.12 \\
\hline Annual & $\mathbf{8 . 6 7}$ & $\mathbf{1 1 . 6 2}$ & $\mathbf{5 . 8 1}$ & $\mathbf{3 . 0 4}$ \\
\hline
\end{tabular}




\subsection{Evaporation}

Evaporation data were obtained from the WRCC for the Aberdeen Experiment Station. The Aberdeen Experiment Station was chosen out of the 14 stations in Idaho where evaporation data has been recorded over several decades as it should best represent evaporation conditions at CFA. The evaporation data provided by WRCC is reported as the monthly average pan evaporation. The average monthly pan evaporation was then adjusted using factors based on temperature to more closely estimate the average evaporation from the lagoons. Using the pan coefficients, it was determined that the annual evaporation for the CFA area is 33.58 inches "pond" evaporation rate (note this is not "pan" evaporation rate). The resulting monthly evaporation rates are summarized in Table 3.

High salt concentrations in wastewater warrant further reducing the evaporation rate with a "salinity correction factor." Results from wastewater samples taken at the CFA indicated a total dissolved solids concentration of 1,460 milligrams per liter (mg/L) in August 2011 and 1,203 mg/L (average) in 2007. These concentrations are the highest concentrations reported in the annual wastewater reuse reports completed for CFA since 2005 and are not high enough to warrant correction for salinity.

Based on this data, the annual net evaporation for the INL area during a "wet" year is estimated to be approximately 22 inches (33.58 inches evaporation - 11.62 inches precipitation).

Table 3. Monthly temperature and evaporation data.

\begin{tabular}{|c|c|c|c|c|}
\hline Month & $\begin{array}{c}\text { Average } \\
\text { Temperature } \\
\left({ }^{\circ} \mathrm{F}\right)^{1} \\
\end{array}$ & $\begin{array}{c}\text { Average "Pan" } \\
\text { Evaporation } \\
\text { (inches) }^{2} \\
\end{array}$ & $\begin{array}{c}\text { Evaporation Pan } \\
\text { Coefficient }\end{array}$ & $\begin{array}{c}\text { Adjusted Average } \\
\text { "Pond" } \\
\text { Evaporation } \\
\text { (inches) })^{3}\end{array}$ \\
\hline January & 16.2 & 0.0 & - & 0 \\
\hline February & 21.3 & 0.0 & - & 0 \\
\hline March & 31.9 & 0.0 & 0.991 & 0 \\
\hline April & 42.1 & 0.0 & 0.888 & 0 \\
\hline May & 51.5 & 7.46 & 0.805 & 6.00 \\
\hline June & 60.0 & 8.95 & 0.721 & 6.45 \\
\hline July & 68.5 & 10.28 & 0.646 & 6.64 \\
\hline August & 66.5 & 9.40 & 0.665 & 6.25 \\
\hline September & 56.1 & 6.41 & 0.758 & 4.86 \\
\hline October & 43.8 & 3.85 & 0.879 & 3.38 \\
\hline November & 29.6 & 0.0 & - & 0 \\
\hline December & 18.4 & 0.0 & & 0 \\
\hline Annual & & 46.35 & & 33.58 \\
\hline
\end{tabular}




\section{SYSTEM EVALUATION}

\subsection{Existing System Drawings}

Available drawings of the existing STP are included in Attachment A. Also, Figure 2 shows an overall view of the lagoon system site.

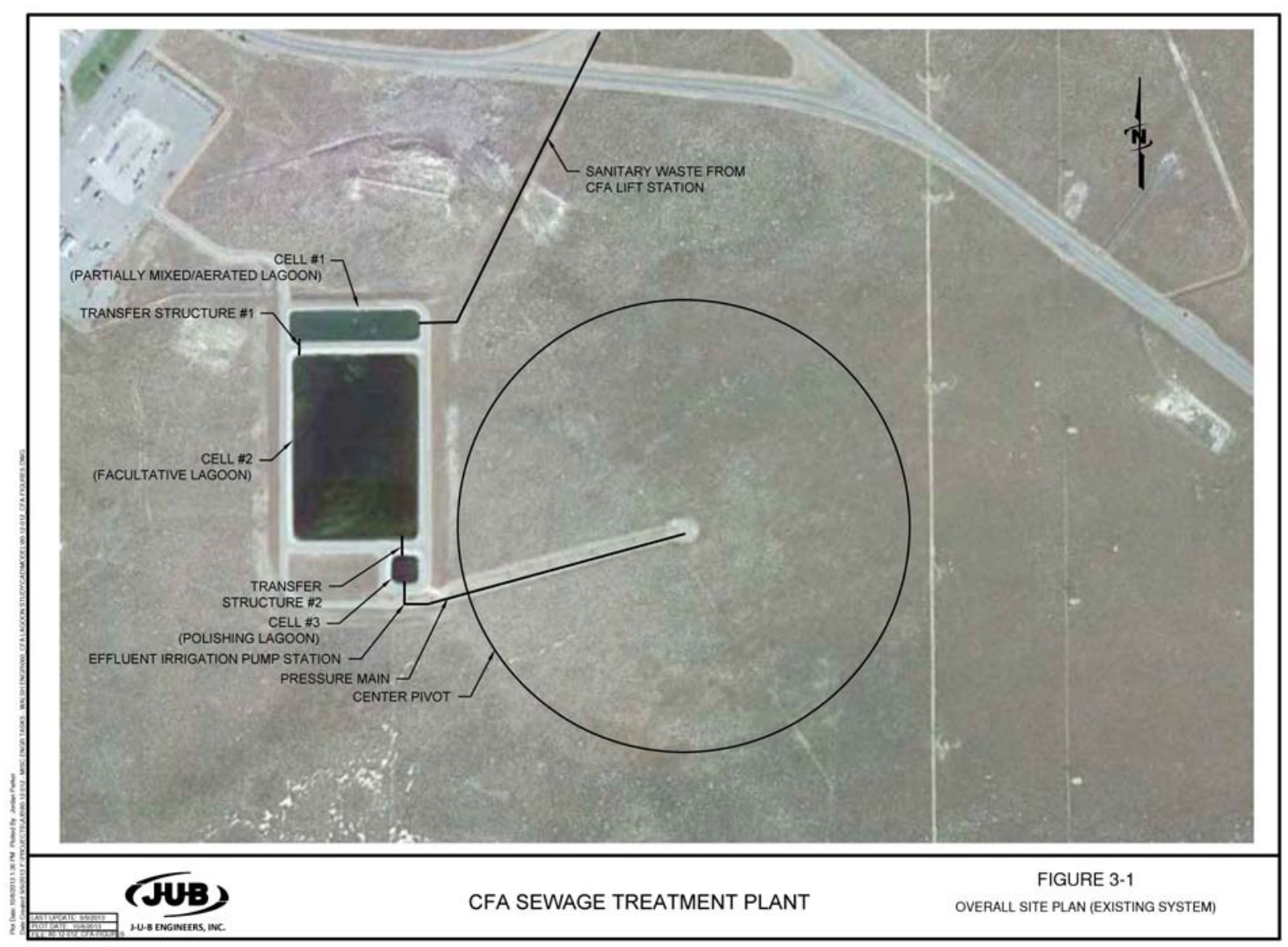

Figure 2. Overall site plan (existing system).

\subsection{Existing System Description}

Sanitary wastewater from the CFA is collected and conveyed through gravity lines to the influent lift station. The duplex submersible pump lift station then pumps the wastewater through a 4-inch pressure main to the lagoons for treatment and disposal via evaporation and the land application system. The discharge of the lift station has an ultrasonic flow meter.

Table 4 summarizes the details of the three lagoons. 
Table 4. CFA existing lagoons.

\begin{tabular}{|c|c|c|l|c|c|}
\hline $\begin{array}{c}\text { Lagoon } \\
\text { Cell No. }\end{array}$ & $\begin{array}{c}\text { Year } \\
\text { Constructed }\end{array}$ & $\begin{array}{c}\text { Approximate } \\
\text { Average } \\
\text { Water Surface } \\
\text { Area (acres) }\end{array}$ & \multicolumn{1}{|c|}{ Liner } & $\begin{array}{c}\text { Maximum } \\
\text { Water Depth } \\
\text { (feet }^{1} \text { ) }\end{array}$ & $\begin{array}{c}\text { Freeboard } \\
\text { above Max } \\
\text { Water Depth } \\
\text { (feet) }\end{array}$ \\
\hline 1 & 1994 & 1.7 & $\begin{array}{l}\text { Bentonite-treated } \\
\text { soil with } \\
\text { riprapped sides }\end{array}$ & 8 & 2 \\
\hline 2 & 1994 & 10.3 & $\begin{array}{l}\text { Bentonite-treated } \\
\text { soil with } \\
\text { riprapped sides }\end{array}$ & 8 & 2 \\
\hline 3 & 1994 & 0.5 & $\begin{array}{l}\text { Bentonite-treated } \\
\text { soil with } \\
\text { riprapped sides }\end{array}$ & 8 & 2 \\
\hline Total & 12.5 & & \\
\hline 1. Design depth. Typical maximum operating depth is approximately 7.5 ft. & \\
\hline
\end{tabular}

Figure 3 and Figure 4 below are photos of the existing lagoons.

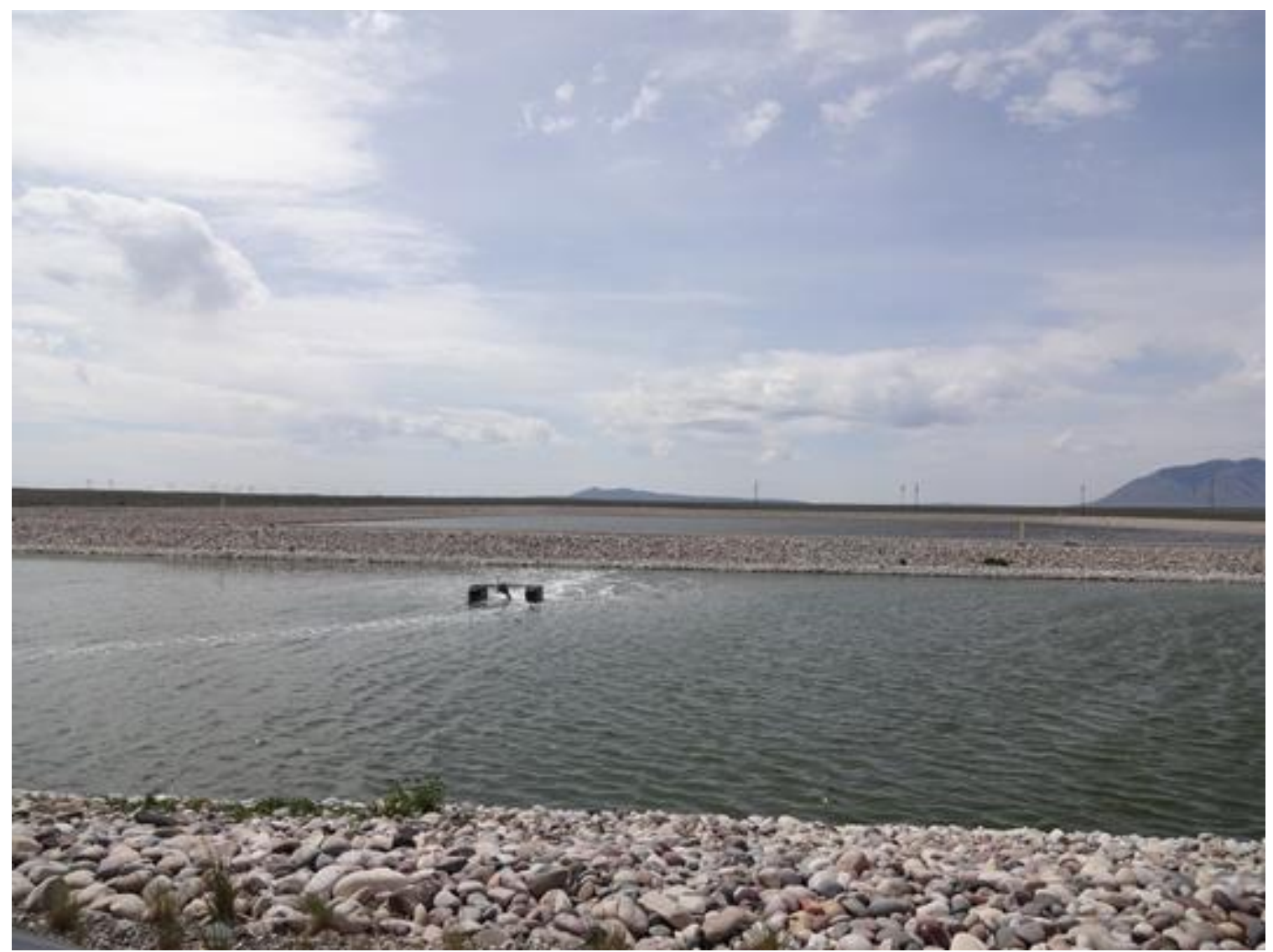

Figure 3. Photo of existing lagoons (Cell 1 in the forefront, Cell 2 behind). 


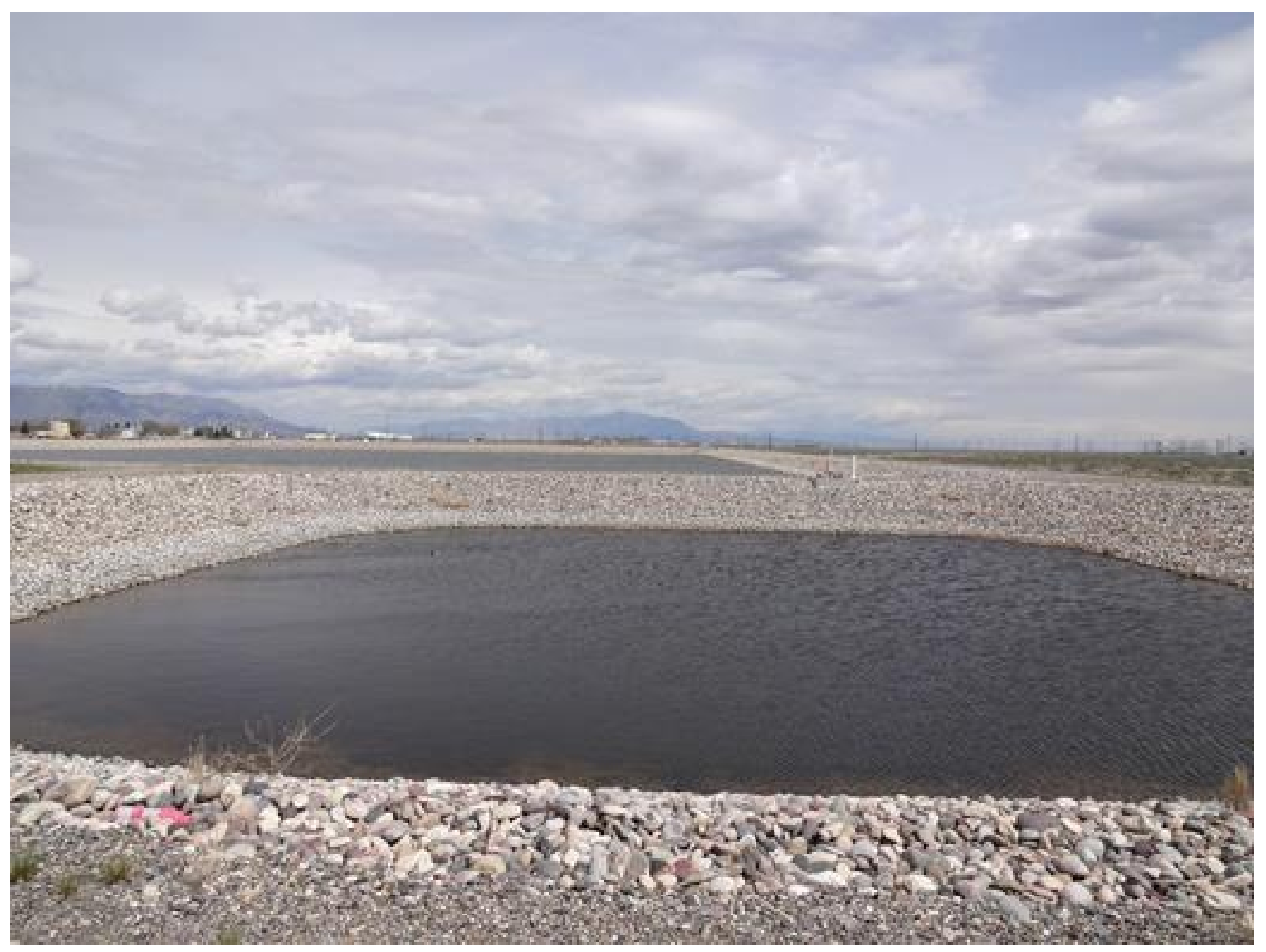

Figure 4. Photo of existing lagoons (Cell 3 in the forefront, Cell 2 behind).

Wastewater from the influent lift station normally enters Cell 1 and flows out the southwest corner through an in-dike Transfer Structure 1 into the adjacent Cell 2. The wastewater then flows from Cell 2 to Cell 3 near the southeast corner of Cell 2 through an in-dike Transfer Structure 2. These transfer structures consist of valves and overflow weirs. The weirs are typically set to maintain an operating depth in the lagoons of between $3 \mathrm{ft}$ and $8 \mathrm{ft}$. Occasionally, the water levels may be lowered for operational and maintenance reasons.

Figure 5 and Figure 6 are photos of both transfer structures. 


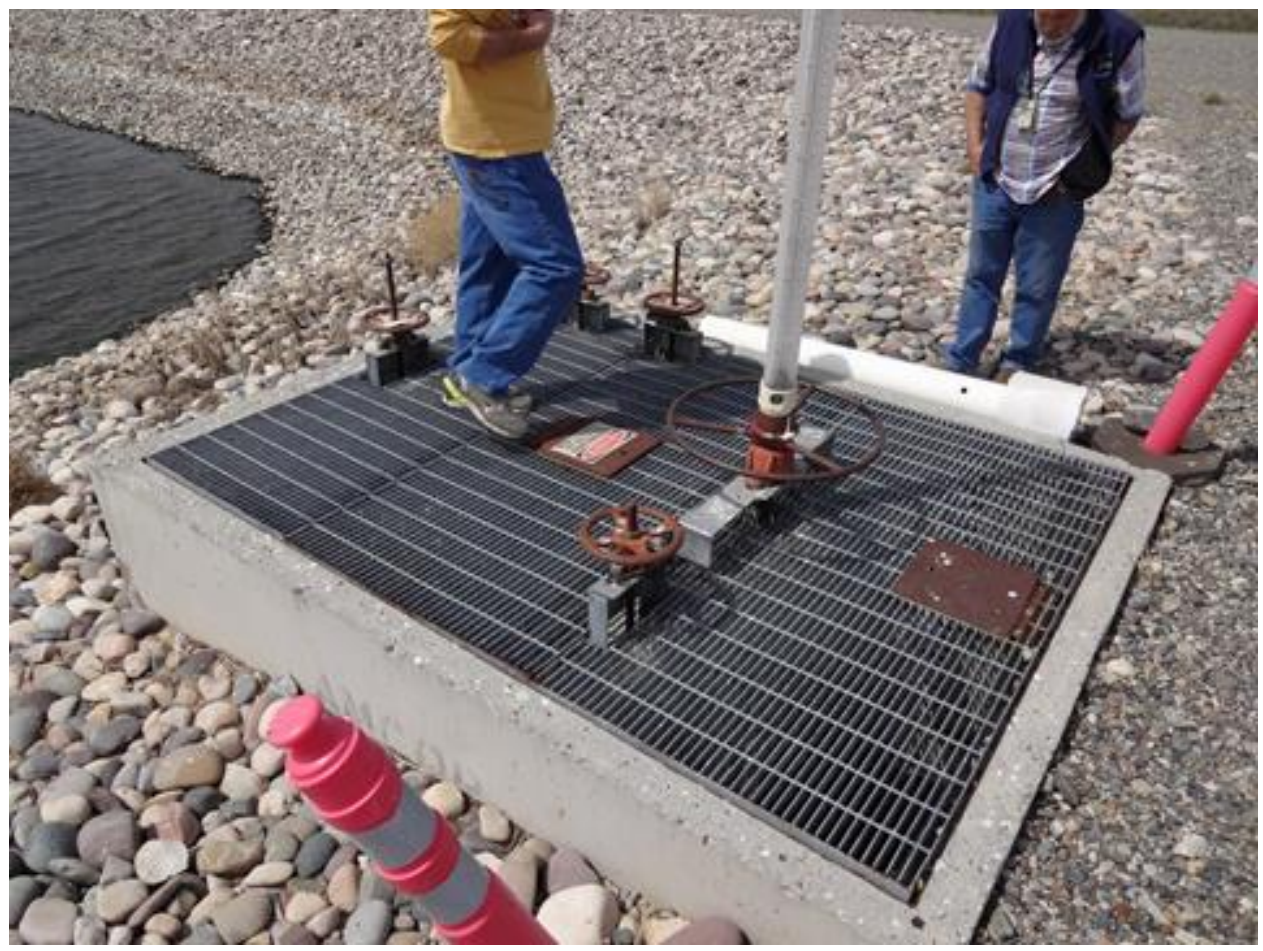

Figure 5. Photo of existing Transfer Structure 1 between Cells 1 and 2.

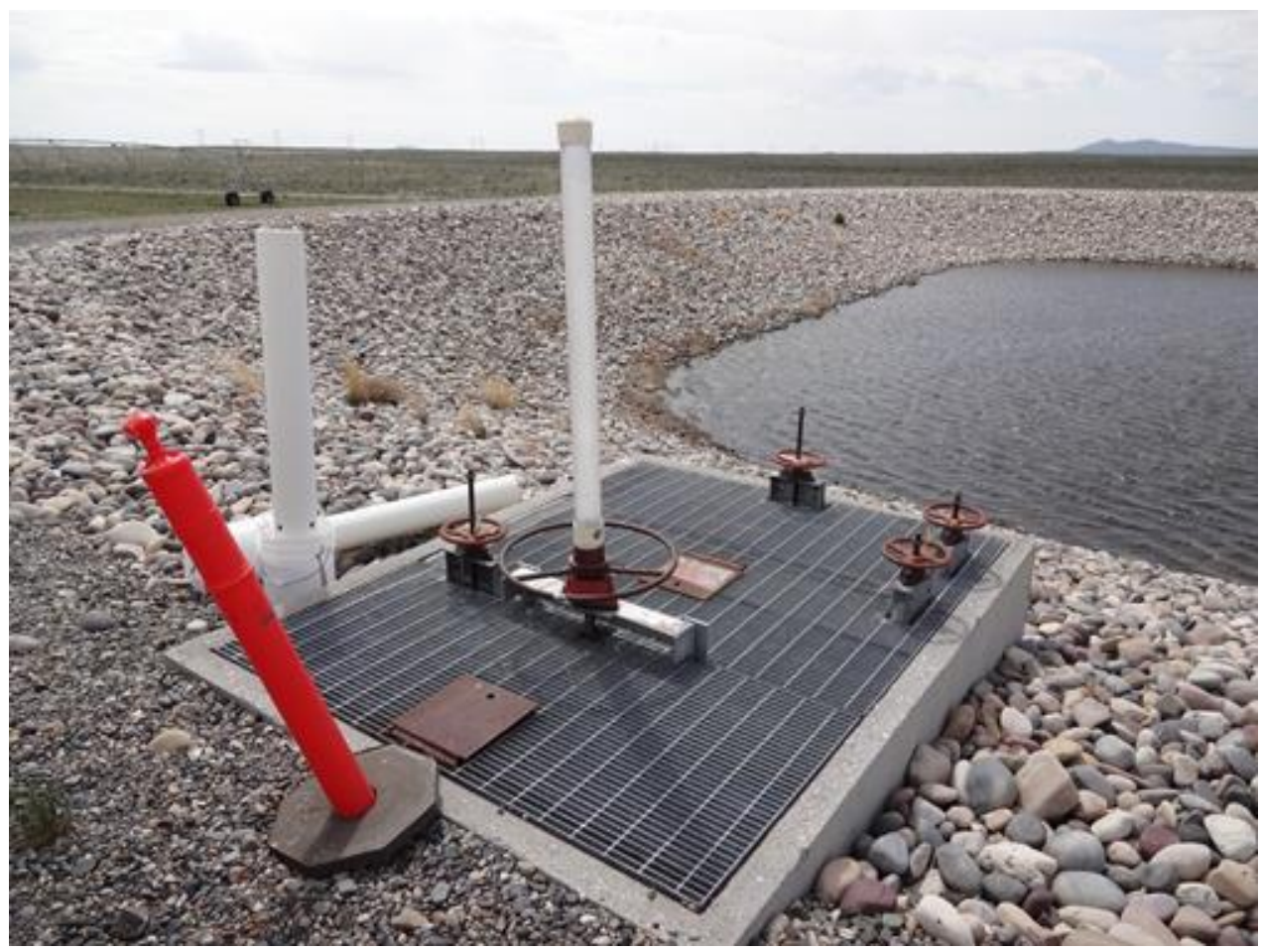

Figure 6. Photo of existing Transfer Structure 2 between Cells 2 and 3.

Following treatment in the lagoons, the wastewater can be pumped out of Cell 3 to the land application center pivot. Figure 7 is a photo of the effluent irrigation pump station that is used to pump the wastewater to the land application site. 


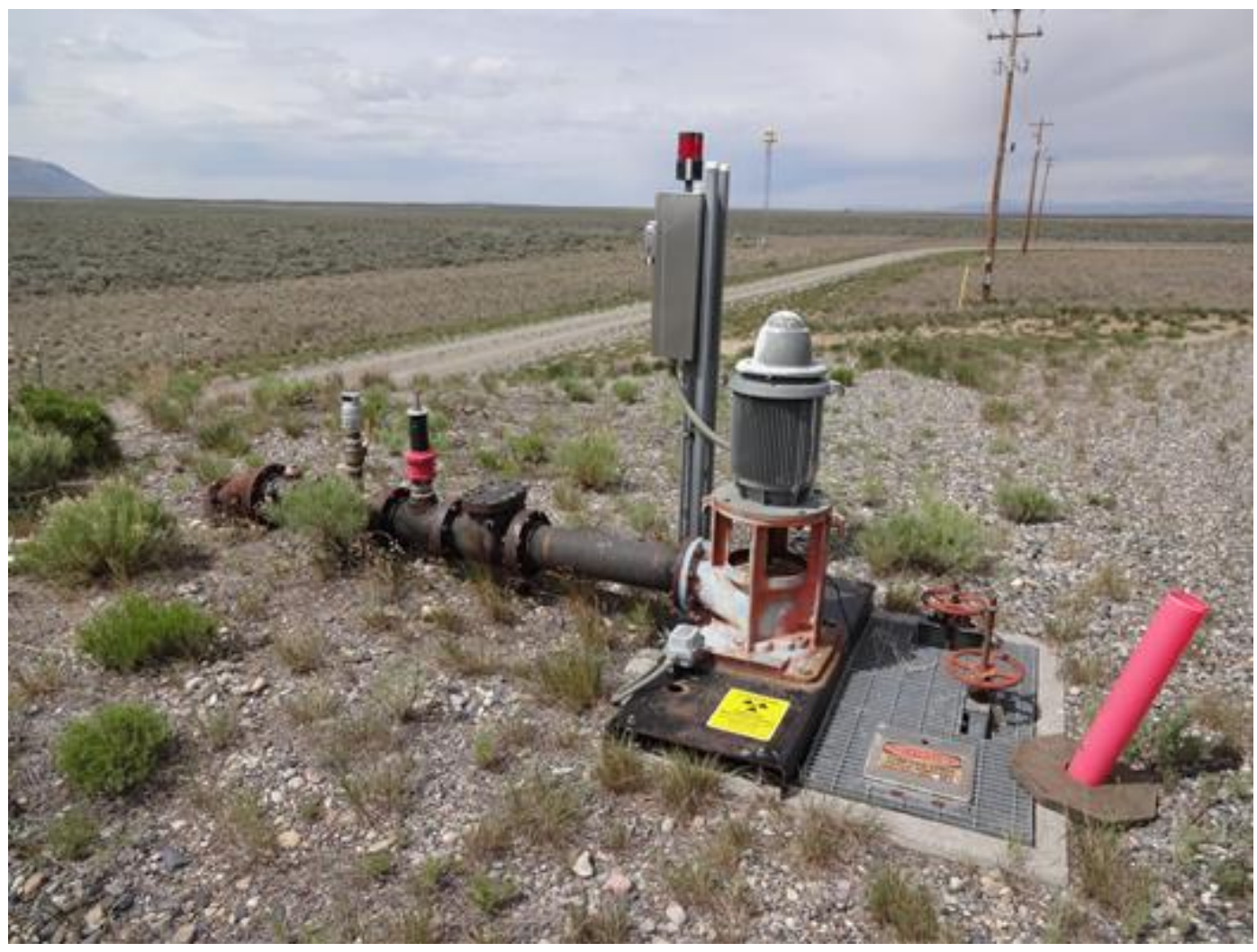

Figure 7. Photo of effluent irrigation pump station.

The lagoon dikes include a 10-feet-wide section of gravel road around the perimeters. The exterior and interior slopes are 3:1 (horizontal: vertical). The lagoon facility is fenced only on the west and south side with a smooth-wire fence, but the fence is not able to keep all animals out of the facility.

\subsection{Service Area Limits and Population}

The service area boundary of the STP is limited to the CFA boundary. However, additional wastewater is transported from other area septic tanks, portable toilets, and a temporary office/laboratory trailers with holding tanks to the CFA STP for treatment. The following information regarding existing and future population at the CFA was provided by BEA. According to current plans, no significant future growth is planned for the population served by the STP. Therefore, future growth projections of population were not considered in this evaluation, and subsequent analyses of the system were based only on the existing CFA population estimates. It was assumed that the existing population and flows are also representative of future population and flows.

Currently, BEA estimates that there are 438 employees who work at the CFA. These employees work a variety of 8 to 12 -hour shifts and 4 to 5 days per week. Less than 50 employees are expected to work at the facility on weekends or night shifts.

Based on an average of 438 employees, the total monthly workforce is estimated to be approximately 9,500 worker-days per month based on a standard 8-hour work-day:

438 workers $x$ (2,080 worker-hours/year) $x$ (1 year/12 months) $x(1$ worker-day/8 worker-hours $)=$ 9,500 worker-days per month. 


\subsection{Flows}

\subsubsection{Existing Flows}

Flow data for the STP were reviewed for the past several years. The annual influent, effluent, and supplemental water flows at the STP for the permit years of 2003 through 2014 are shown graphically in Figure 8.

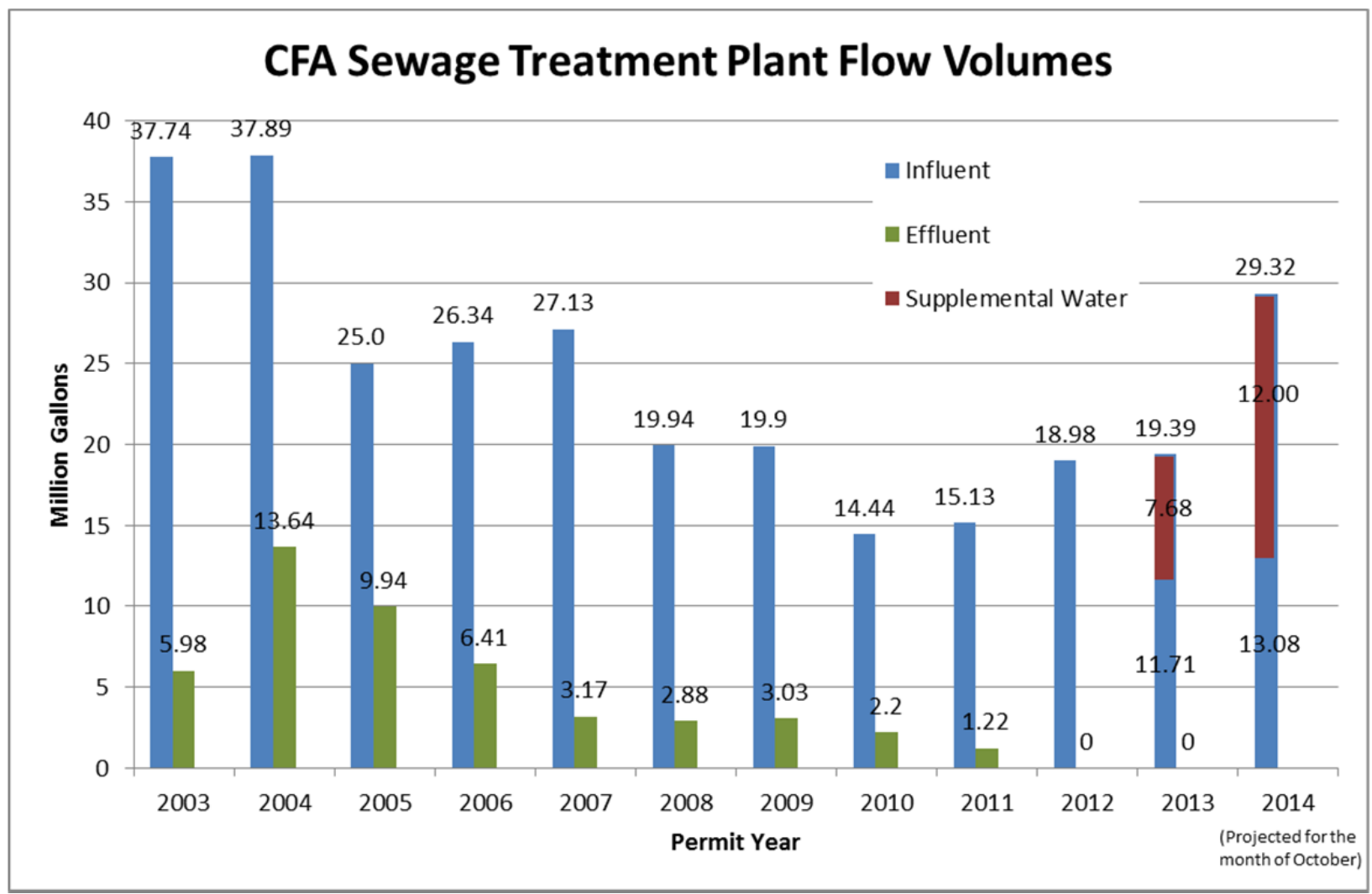

Figure 8. CFA STP annual flow volumes. ${ }^{a}$

In Figure 8, the annual influent flows shown for each permit year are based on flows starting November 1 of the previous year and ending October 31 of the year shown. Influent flow for October 2014 was estimated since the flow data were not available prior to the completion of this report. Supplemental flow values for 2013 and 2014 were estimated based on information reported by BEA staff.

Monthly influent flows for the period of November 2007 through October 2014 are shown graphically in Figure 9.

\footnotetext{
a The facility's permit year is from November 1 of the previous year to October 31 of the current year. Annual influent and effluent flows for 2003 and 2004 were reported by BEA staff. Influent and effluent flows for 2005 through 2009, and effluent flows for 2010 and 2011 were obtained from the daily flow data reported in the appendix of the annual Wastewater Land Application Site Performance Reports submitted to IDEQ. Influent flows for 2010 through 2013 were obtained from daily flow records provided by BEA staff, and missing data were filled in using average values. Influent flow for October 2014 was estimated since flow data were not available prior to the completion of this report. Supplemental flow for 2013 and 2014 was estimated based on information reported by BEA staff. Values prior to August 2013 should be reduced to reflect flowmeter re-calibration by a factor of approximately 0.87 .
} 


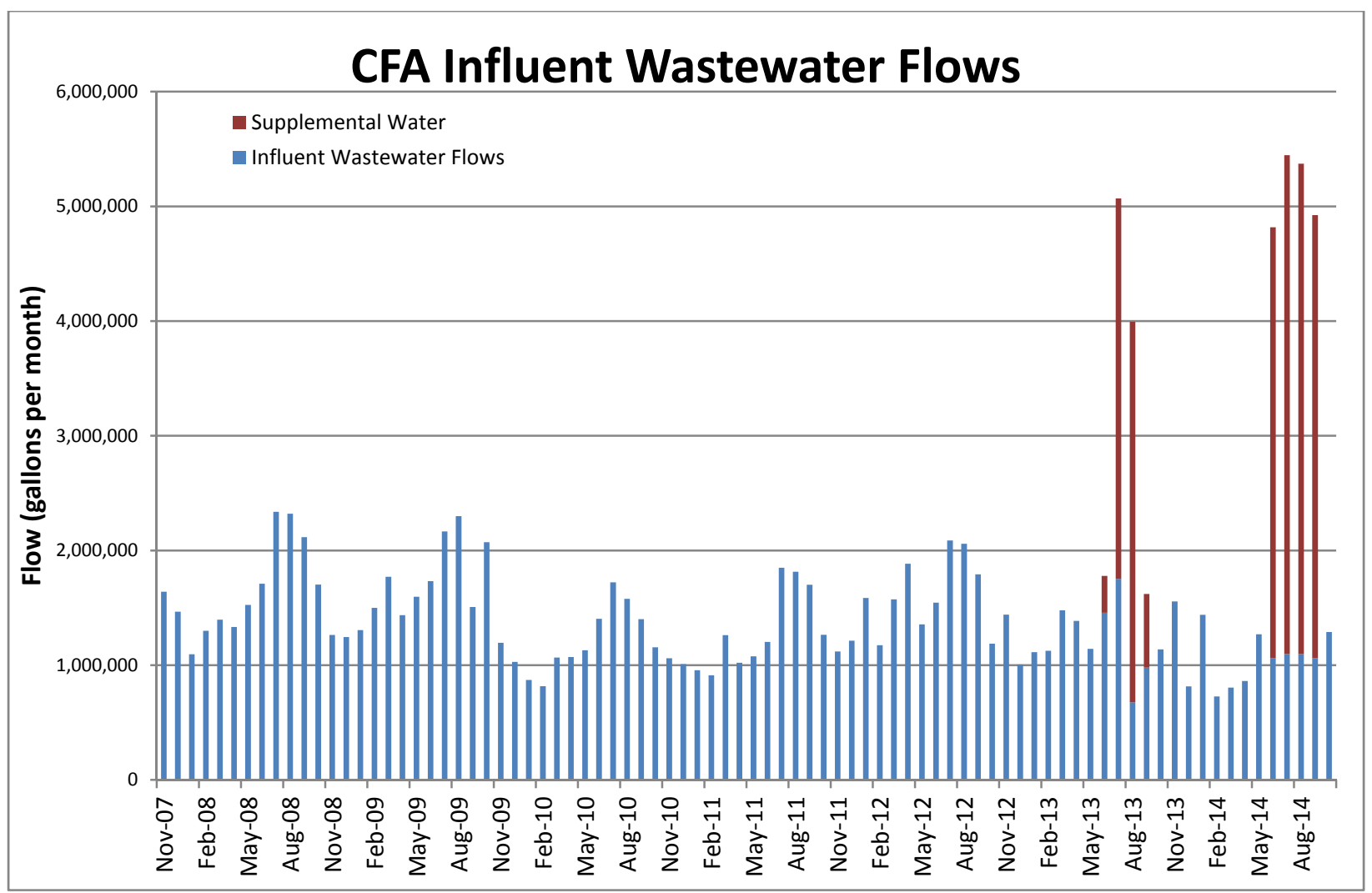

Figure 9. CFA STP monthly influent flow volumes.

As shown in Figure 8 and Figure 9, supplemental water has been discharged to the STP in recent months to maintain a minimum water level to keep the clay liners from drying. However, it should be noted that the high volume of supplemental water for 2014 was partially a result of filling the lagoons in preparation for seepage testing and not just for maintaining a minimum water level.

Based on conversations with BEA staff, it was assumed that the average monthly flow for the most recent 3 years, October 2010 through September 2014, excluding the supplemental water, would be representative of current and future flows and suitable for the analyses in this current study. Data from the influent lift station flow meter for this period of time indicates:

- Sanitary wastewater and non-contact cooling water flow

- $\quad$ Average daily $=35,400$ gallons per calendar day (gpd)

- $\quad$ Average annual $=12,900,000$ gallons per year

Based on this average influent flow data, the average sanitary flow per worker is 113 gallons per worker-day:

12,900,000 gallons/year $x$ (1 year/12 months) $x(1$ month/9,500 worker-days $)=113$ gallons per worker-day 
For comparison, literature indicates an "office" facility typically uses about 13 gallons per day per worker (Metcalf \& Eddy, 2003). The higher flows at CFA could partially be a result of the additional non-contact cooling water that is discharged to the STP. In addition to the sanitary wastewater and the non-contact cooling water flows at the CFA, the STP also receives additional flow from septic tanks, portable toilets, and temporary office/laboratory trailers with holding tanks, which effectively increases the actually population served by the STP. As noted earlier, there may be lingering issues with accuracy of the influent flow meter which should be further investigated.

It should be noted that Figure 9 reflects supplemental water values for 2014 that were calculated by subtracting the average daily flow of 35,400 gpd from the reported flow meter data for each month. The resulting total supplemental water of $16.2 \mathrm{MG}$ for 2014 is significantly higher than the $12 \mathrm{MG}$ estimated by the operators.

For the purpose of this study, it was assumed that the influent flow data reported after the flow meter was serviced are accurate. If it is determined that the reported influent flow data are not representative of actual flows, the water model and observations discussed later in this report should be updated.

\subsubsection{Flow Meter Correction Factor}

As previously mentioned, the flow meter in the influent lift station was serviced and recoupled in July 2013. A correction factor was estimated to reflect the differences in flow measurements that may have resulted from servicing the flow meter. This correction factor can then be used to "correct" influent flow data collected prior to July 2013. The factor is basically a ratio comparing the average influent flows after the flow meter was serviced to the average influent flows before the flow meter was serviced.

After the influent flow meter was serviced, BEA collected influent flow data from October 2013 through October 2014. During June, July, August, and September 2014, large amounts of supplemental water were being added to the lagoons in preparation for the lagoon seepage testing. An average of the influent flow data was calculated using the months during which no supplemental water was added to the lagoons. This average influent flow, calculated for data from after the flow meter was serviced, is approximately 0.0354 million gallons per day (mgd) as shown in Figure 10.

Influent flow data from before the influent flow meter was serviced were also provided by BEA. An average of the influent flow was calculated using data from October 2010 through July 2013. This average also did not include data from any of the months of June through September when supplemental water may have been added. This average influent flow, calculated for data from before the flow meter was serviced, is approximately $0.0405 \mathrm{mgd}$ as shown in Figure 10.

The flow meter correction factor was calculated as a ratio of the average influent flows after the flow meter was serviced to the average influent flows before the flow meter was serviced. The resulting flow meter correction factor is approximately 0.87 . This flow meter correction factor is used to correct the influent flow data collected prior to July 2013. 


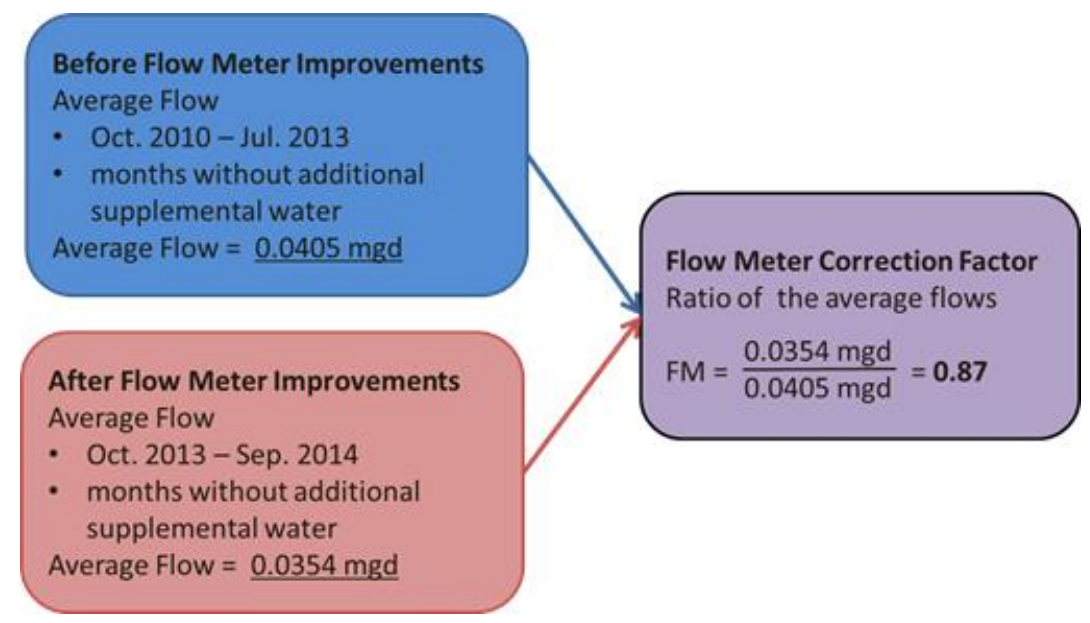

Figure 10. Flow meter correction factor.

\subsubsection{Input Flow Data for the Year 2013 Comparison Model}

For the Year 2013 comparison model, monthly influent flow data from the following periods were used:

- January 2013 - July 2013

- This was reported data from before the flow meter was serviced; therefore, the data were reduced by the correction factor of 0.87 .

- Reported supplemental water was removed from June and July measurements.

- $\quad$ August 2013 - September 2013

- This was reported data from after the flow meter was serviced.

- Reported supplemental water was removed from August and September measurements.

- October 2013 - December 2013

- This was reported data from after the flow meter was serviced.

\subsubsection{Input Flow Data for the "Working" Water Balance Model}

For the "working" water balance model, monthly influent flow data from October 2010 through September 2014 were used as follows:

- October 2010 - July 2013

- This was reported data from before the flow meter was serviced; therefore, the data was reduced to reflect flow meter servicing by the correction factor of 0.87 .

- Reported supplemental water was removed from June through September measurements.

- $\quad$ August 2013 - September 2014

- This was reported data from after the flow meter was serviced.

- Reported supplemental water was removed from June through September measurements. 


\subsection{Water Balance}

An updated water balance spreadsheet model of the lagoons and land application system was developed using the influent flow, evaporation, precipitation, and seepage data discussed earlier in this report. Year 2013 was selected to compare the model's results to actual observations for that year and better understand the limitations and accuracy of the model. Then a "working" version of the model was developed using input data for both "wet" year and "dry" year conditions for the purpose of evaluating various scenarios and alternatives.

The water balance spreadsheet model was prepared assuming that the water level fluctuates simultaneously in all three lagoons as occurs when the valves in the transfer structures are open. In this mode of operation, as water starts to fill the lagoons, all three lagoons rise at the same rate, and as water is lost to evaporation or land application, the water level in all three lagoons falls at the same rate. A 1-year cycle of the lagoon water levels was evaluated to show the water level fluctuation over the course of a complete water cycle season. For this analysis, a water cycle season was assumed to start on October 1, which is when the system should generally be at its lowest level in the annual cycle.

For the purposes of this study, the model did not include supplemental water addition or reuse water discharge. The difference in the accumulated volume stored in the system between the start and the end of the annual cycle was used as an estimate of the annual volume of either supplemental water addition or discharge to reuse that would be required to make the system balance for the given set of input data.

\subsubsection{Updated Comparison Model for 2013}

The month-to-month water balance for the STP and the land application system based on the calibration model for Year 2013 conditions is shown in Figure 11 for the 1-year water cycle period. In this model, an initial storage volume of $21.5 \mathrm{MG}$ was assumed. The model used actual 2013 precipitation data, the seepage rate from the 2014 testing, and the 2013 influent flow data discussed earlier in Section 3.4.3. 


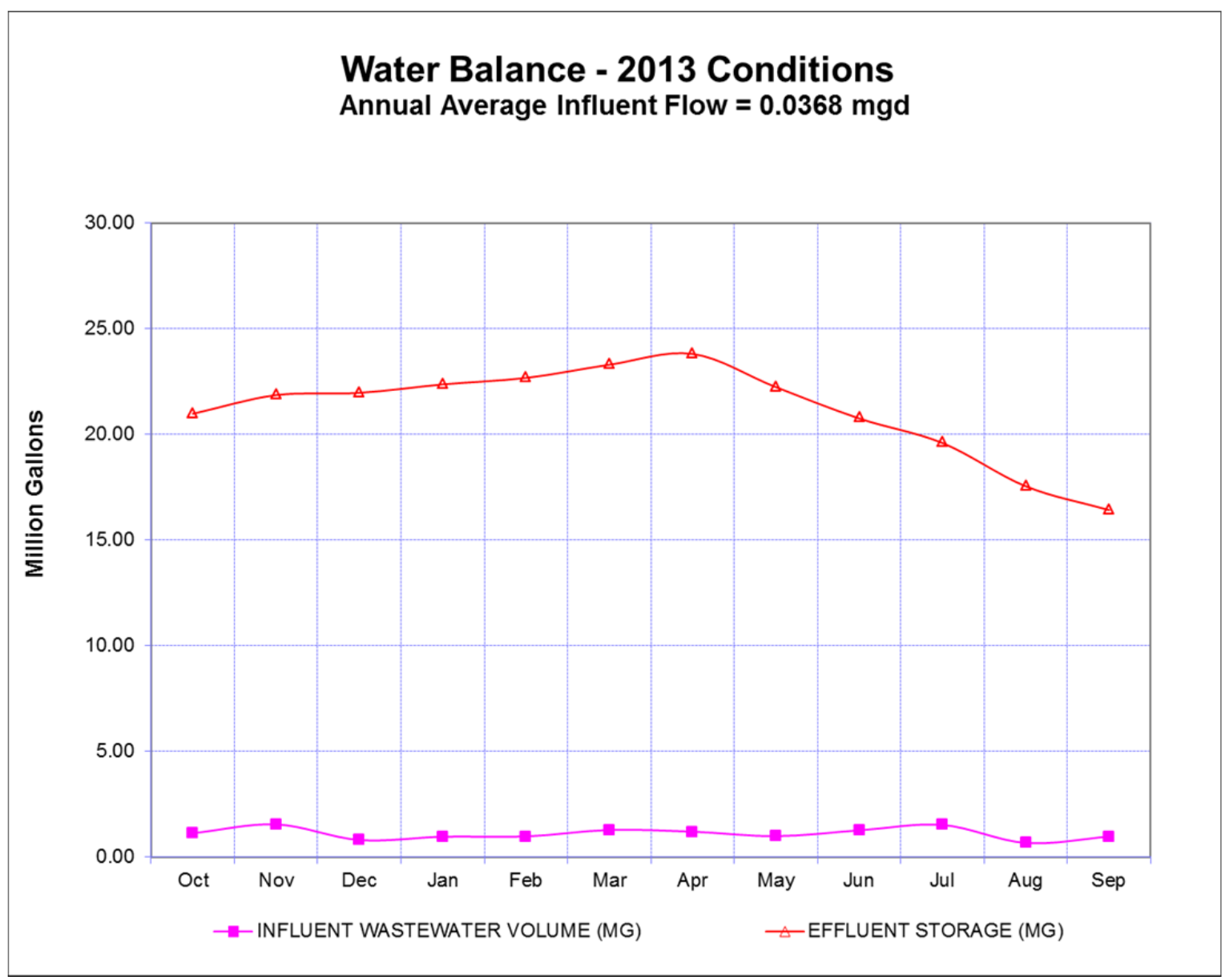

Figure 11. Water balance - updated comparison model, Year 2013.

As seen in the above figure, the accumulated volume of stored wastewater in the system at the end of the annual cycle is approximately 5.1 MG less than at the start of the annual cycle. This indicates that with the assumed input data, approximately $5.1 \mathrm{MG}$ of additional supplemental water would be needed to make the system balance.

This result can be compared to actual operations during 2013 when operators reported that approximately 7.7 MG of supplemental water were added to the lagoons to keep a minimum water level. Although the updated model results match the reported operations of the system reasonably well, some of the remaining discrepancy could be due to flow meter inaccuracies. If actual influent flows are actually lower than recent data indicate, reducing the influent flows input to the model would increase the amount of supplemental water needed to balance the system. Nevertheless, the combination of updated influent flow and seepage rate data seem to have significantly increased the accuracy of the model as the previous dry year water model developed in the December 2013 study indicated that only 1.9 MG of reuse would be required. 


\subsection{2 "Working" Model for Existing Conditions}

The month-to-month water balance for the STP and the land application system based on the model for existing "wet" and "dry" year conditions is shown in Figure 12 for the 1-year water cycle period. In this "working" model, an initial storage volume of $10 \mathrm{MG}$ was assumed. The model used the seepage rates from the 2014 testing, 10-year high for "wet" and 10-year low for "dry" precipitation scenarios, and the average influent flow data discussed earlier in Section 3.4.4. The lagoon water levels were also limited to the maximum depths established during the 2014 seepage testing.

\section{Water Balance \\ Annual Average Influent Flow $=0.0354 \mathrm{mgd}$}

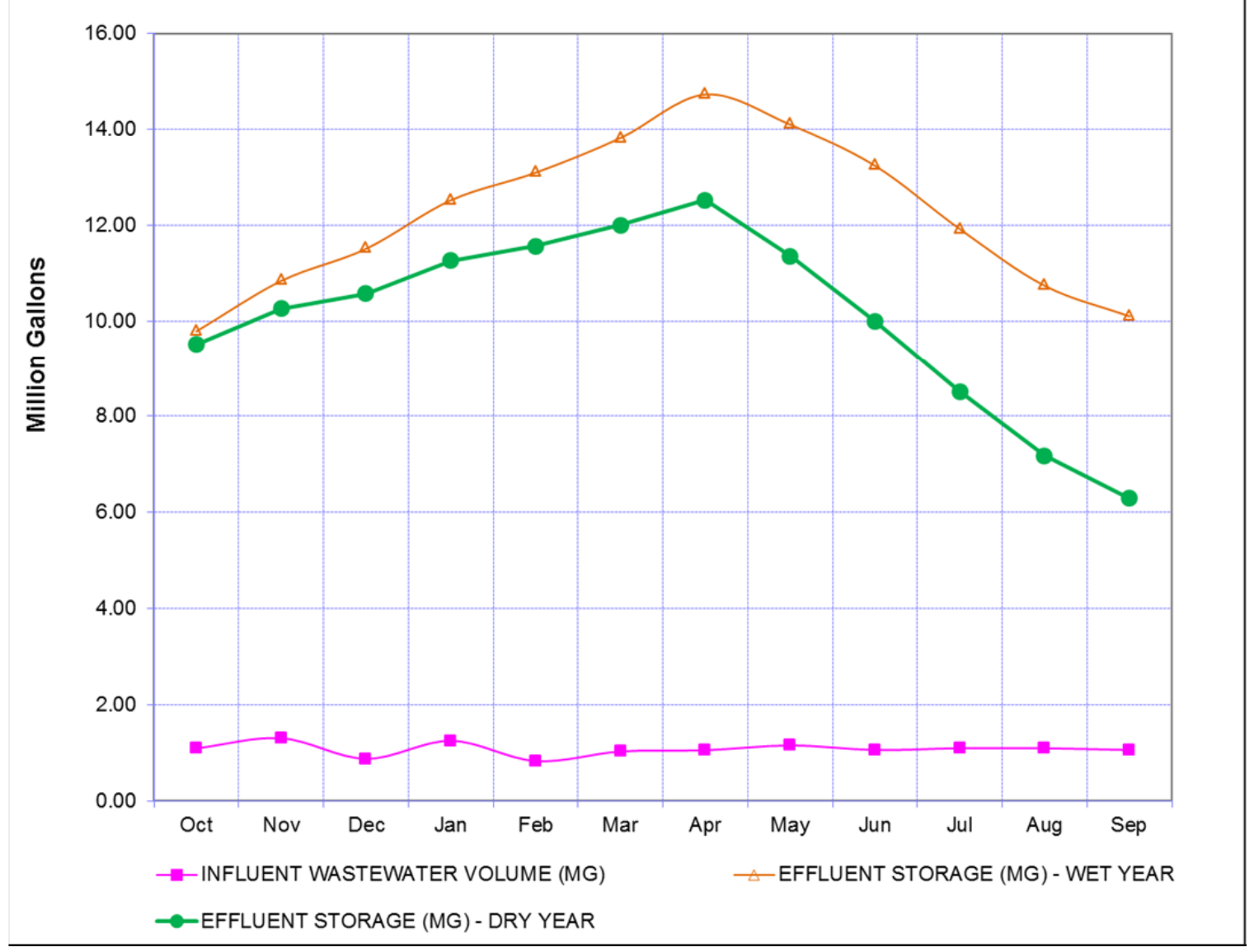

Figure 12. Water balance -“wet" year and "dry" year scenarios.

As seen in the above figure for a "dry" year, the model indicates that 3.7 MG supplemental water would need to be added to the lagoons annually to maintain the balance. For a "wet" year, $0.1 \mathrm{MG}$ would be need to be discharged to reuse annually.

This model will be used later in Section 4 to evaluate various improvement alternatives. 


\subsection{Needs and Deficiencies}

The identified needs and deficiencies of the existing STP system are summarized in the following subsections.

\subsubsection{Addition of Supplemental Water}

One of the primary concerns is the large volume of supplemental water that has been added to the lagoon system in recent times to maintain a minimum water level in the lagoons. Providing supplemental water requires significant infrastructure and energy resources and conflicts with the site's sustainability goals and objectives.

Since the control of seepage from the lagoons relies on the integrity of the clay liners, a water cap must be maintained in the lagoons to prevent drying and cracking. The addition of supplemental water should be continued as needed to maintain the water cap until influent flows increase to maintain the water cap or modifications are made to the STP to address the problem.

\subsubsection{Seepage Testing}

A recent seepage test for the lagoons was completed in August and September of 2014. Cells 1 and 2 passed the test with seepage rates below the maximum allowable seepage rate of $0.25 \mathrm{in} /$ day as established in IDAPA 58.01.16. Cell 3 exceeded the maximum allowable seepage rate and will need to be re-lined or removed from operation. In accordance with DEQ Rules (IDAPA 58-01-16), the lagoons will require testing again if a change of condition to the liner occurs (e.g., the liner is replaced) and also at a frequency of every 10 years.

\subsubsection{Influent Flow Monitoring}

As discussed previously, the accuracy of the influent flow measurements have been questioned and the values seem unreasonably high. Therefore, further investigation is recommended.

\subsubsection{Influent Lift Station}

STP operators reported that the pump guide rail system in the influent lift station appears to be deteriorating and will likely need to be replaced within approximately 5 years. The condition of the guide rail system and other components of the influent lift station should be monitored and replaced when their conditions warrant replacement.

\subsubsection{Collection System}

The STP operators report that the collection system consists of a combination of concrete pipe and PVC pipe and is in fairly good condition with no known deficiencies. The collection system should continue to be cleaned and maintained in accordance with the established maintenance schedule.

\subsubsection{Land Application System}

Facility operators have reported that the irrigation pump, pivot, and other components of the land application system are in good condition and operate as intended. Although the land application system has not been used in recent years, the system and the associated wastewater reuse permit should be maintained until it can be confirmed that reuse will no longer be required for future flows. The current Wastewater Reuse Permit from DEQ will expire on March 16, 2015. Unless it has been determined that the land application system is no longer needed, the permit should be renewed. 


\subsubsection{Transfer Structures}

STP operators have reported that the weirs and gate valves located in the transfer structures between the lagoons appear to be aging and showing signs of wear-and-tear. They have estimated that the components inside the transfer structures will likely need to be replaced within approximately 10 years. The weirs and valves should continue to be serviced and maintained in accordance with manufacturer's recommendations to maximize the remaining service life.

\subsubsection{Fencing and Signage}

\subsubsection{Lagoons}

The IDEQ requirements for wastewater lagoons state:

Fencing. The pond area shall be enclosed with an adequate fence to prevent entering of livestock and discourage trespassing. This requirement does not apply to pond areas which store or impound Class A municipal reclaimed effluent. IDAPA 58.01.16.493.09.c.i

Warning Signs. Appropriate permanent signs shall be provided along the fence around the pond to designate the nature of the facility and advise against trespassing. At least one (1) sign shall be provided on each side of the site and one (1) for every five hundred (500) feet of its perimeter. IDAPA 58.01.16.493.09.c.iii

Currently, the lagoons are only fenced on the west and south sides with a smooth wire fence. It is recommended that additional fencing be installed to enclose the lagoons on all sides to meet the requirements of the above referenced requirements. If completed, the existing smooth-wire fence may be sufficient to keep livestock out but may not be sufficient to reliably keep wildlife out. If livestock or wildlife intrusion in the lagoons is regularly observed, the replacement of the fence around the lagoons to provide a more substantial barrier is recommended to help protect the integrity of the lagoon liners when the water level is low. In addition, it is recommended that STP operators verify that the signs are installed to meet the requirements and add additional signs where necessary.

\subsubsection{Land Application Site}

The current Municipal Wastewater Reuse Permit (LA-000141-03) issued by IDEQ does not state that the land application site must be fenced.

The Reuse Permit does require posting of signs reading "Sewage Effluent Application - Keep Out" or equivalent, every 500 feet and at each corner of the outer perimeter of the buffer zones. It is recommended that STP operators verify that sufficient signs are installed, and if not, that additional signs are installed to meet this requirement. 


\section{ALTERNATIVES EVALUATION \\ 4.1 Screening of Alternatives for Further Evaluation}

To address the primary concerns of eliminating or minimizing the need to add supplemental water to the lagoons and achieving compliance with DEQ's allowable seepage limits for Cell 3, the following alternatives were developed for consideration and screening:

- Alternative 1: Do Nothing. Retain the existing system "as-is."

- Alternative 2: Re-Line Cell 3 Only. Replace the existing clay liner in Cell 3 with a geosynthetic (e.g., high density polyethylene [HDPE]) liner system.

- Alternative 3: Re-Line Storage Cells. Replace the existing clay liners in the 3 storage cells with a new geosynthetic liner system.

- Alternative 4: Abandon Storage Cell 3 - Abandon Cell 3 but retain the existing clay liners in Cells 1 and 2. Reconfigure the effluent irrigation pump station to pump to reuse directly out of Cell 2 .

- Alternative 5: Abandon Storage Cell 3 and Reconfigure Storage Cell 2. Abandon Cell 3 and reduce the size of Cell 2 by approximately $50 \%$ as well as divide Cell 2 into two cells for redundancy. Re-line Cells 1 and 2 with geosynthetic liners.

\subsubsection{Alternative 1: Do Nothing}

As discussed earlier, the water balance model with values based on new seepage data, and more accurate flows indicates that land application may be necessary during wet years and supplemental water may be needed during dry years to maintain operational levels and prevents the clay liners from drying and cracking.

The "do nothing" alternative is not recommended for further consideration for two reasons:

- The addition of large amounts of supplemental water conflicts with the site's sustainability goals and should not be relied on as a long-term practice.

- The "do nothing" alternative would not address the failed liner in Cell 3.

\subsubsection{Alternative 2: Re-Line Cell 3 Only}

For this alternative, the existing clay lining system in Cell 3 would be replaced with a new geosynthetic liner system.

- The new geosynthetic lining system would be designed to comply with DEQ's allowable seepage limits and resolve the current compliance issue.

- Cell 3 could be allowed to go dry without damaging the integrity of the liner material.

- Cell 3's allowable operation would be restored to its 8-ft.-maximum water level.

- The water model indicates that:

- Approximately 1.6 MG of discharge to reuse would be required during wet years.

- Approximately 2.2 MG of supplemental water would be required during dry years.

- Because discharge to reuse would still be required during a wet year under this scenario, this indicates that the existing lagoon system is not adequately sized to operate as a total containment (i.e., evaporation-only) system and continued reliance on the reuse system will be necessary. (However, note that if the influent flows are actually much lower, this conclusion may not be accurate.) 
To implement this alternative, the following improvements would be needed:

- Remove and dispose of accumulated biosolids in accordance with a sludge management plan approved by the state and following Environmental Protection Agency (EPA) 40 Code of Federal Regulations (CFR) 503 rules. A Comprehensive Environmental Response, Compensation, and Liability Act (CERCLA) evaluation would likely be needed to assess whether disposal or land application can be used.

- Reconfigure the lagoon bottom to provide a bottom slope. Replacing the entire liner system will require removal of other unsuitable materials such as riprap and clay and reconstruction of the lagoon bottom to provide a suitable base for the new liner. While these disturbances are occurring, it is recommended to reconfigure the bottom of the cell to allow any gas that is generated under the new liner to migrate to the lagoon perimeter where it can safely escape. Gas can be generated by decomposing organic matter present in the native soils or from wastewater collecting under the liner from leaks.

- Install a new geosynthetic lining system and perform new seepage test to verify compliance with DEQ's allowable seepage limit for new lagoons.

\subsubsection{Alternative 3: Re-Line All Cells}

For this alternative, the existing clay lining system in Cells 1, 2, and 3 would be replaced with a new geosynthetic liner system.

- The new geosynthetic lining system would be designed to comply with DEQ's allowable seepage limits and resolve the current compliance issue.

- All cells could be allowed to go dry without damaging the integrity of the liner material. Therefore, no supplemental water addition would be required.

- The allowable level of operation for Cells 2 and 3 would be restored to their 8 -ft.-maximum water level.

- The water model indicates that:

- Approximately 7.9 MG of discharge to reuse would be required during wet years and 4.0 MG during dry years. However, this is still well below the $37 \mathrm{MG}$ per year allowed by the facility's existing wastewater reuse permit.

To implement this alternative, the following improvements would be needed for each cell:

- Remove and dispose of accumulated biosolids in accordance with a sludge management plan approved by the state and following Environmental Protection Agency (EPA) 40 Code of Federal Regulations (CFR) 503 rules. A Comprehensive Environmental Response, Compensation, and Liability Act (CERCLA) evaluation would likely be needed to assess whether disposal or land application can be used.

- Reconfigure the lagoon bottom to provide a bottom slope. Replacing the entire liner system will require removal of other unsuitable materials such as riprap and clay and reconstruction of the lagoon bottom to provide a suitable base for the new liner. While these disturbances are occurring, it is recommended to reconfigure the bottom of the cell to allow any gas that is generated under the new liner to migrate to the lagoon perimeter where it can safely escape. Gas can be generated by decomposing organic matter present in the native soils or from wastewater collecting under the liner from leaks.

- Install a new geosynthetic lining system and perform new seepage testing to verify compliance with DEQ's allowable seepage limit for new lagoons. 


\subsubsection{Alternative 4: Abandon Cell 3}

For this alternative, Cell 3 would be abandoned; the effluent irrigation pump station would be reconfigured to allow discharge to the reuse pump station wet well directly from Cell 2, and the existing clay liner system would be retained in Cells 1 and 2.

- Abandoning Cell 3 would restore compliance of the facility with DEQ's allowable seepage limits.

- The water model indicates that:

- Approximately 1.6 MG of discharge to reuse would be required during wet years.

- Approximately 2.2 MG of supplemental water would be required during dry years.

- These values are similar to those for Alternative 2 as Cell 3 only provides approximately $1 \mathrm{MG}$ of storage ( $6 \%$ of the system total) and 0.5 acres of surface area ( $7 \%$ of the system total).

- Impacts to treatment effectiveness would need to be addressed if Cell 3 is eliminated. The existing reuse permit from DEQ lists Cell 3 as a "polishing lagoon." DEQ may require engineering justification for eliminating this cell to confirm that treatment goals will still be achieved prior to reuse. Without accounting for mixing inefficiencies, Cell 2 alone provides up to 680 days of detention time at current flows, which is much more than necessary for facultative treatment. Therefore, if Cell 3 is eliminated, any impact to treatment from the reduction in overall detention time should be insignificant.

- $\quad$ The large volume of Cell 2 also provides ample detention time for solids settling even without Cell 3.

- If Cell 3 is eliminated, the STP would have only one storage cell (Cell 2). When required for maintenance or during seepage testing, Cell 1 would need to be temporarily lowered and operated as a storage cell to allow isolation and bypassing of Cell 2.

To implement this alternative, the following improvements would be needed:

- Abandon Cell 3 in accordance with INL requirements and an IDEQ-approved closure plan meeting the requirements of IDAPA 58.01.16.493.10. Abandonment would likely include removal and proper disposal of accumulated solids, the embankment liner, piping, and structures and smooth grading of the site.

- Reconfigure the piping and valving to allow conveyance of effluent directly from Cell 2 to the effluent irrigation pump station wet well.

\subsubsection{Alternative 5: Abandon Cell 3 and Reconfigure Cell 2}

For this alternative, Cell 3 would be abandoned and Cell 2 would be reconfigured to reduce the storage volume and divided into two cells for redundancy. Cells 1 and 2 would be relined with a geosynthetic liner.

- Abandoning Cell 3 would restore compliance of the facility with DEQ's allowable seepage limits.

- Dividing Cell 2 into two cells would allow isolation or bypassing when needed for maintenance or during seepage testing. 
- Because of impacts to the existing clay liner during earthwork construction of the new center dike and the difficulties associated with a "leak-proof" connection of the new liner with the existing clay liner, it is recommended that a new geosynthetic lining system be included as part of this alternative. Also, a much thicker layer of clay with strict construction tolerances would be necessary to meet IDEQ's requirement for a maximum design seepage rate of 500 gallons per day per acre for "new" lagoon construction. (Note that this is 8 times more stringent than IDEQ's maximum operating design seepage rate of 3,400 gallons per day per acre [0.125 in/day] for existing lagoons). Relining Cells 1 and 2 would restore the allowable operation of the cells to an 8-ft.-maximum water level and eliminate the need to add supplemental water as the lagoons could be allowed to go dry without damaging the integrity of the clay material.

- To save liner cost, the size of Cell 2 could be reduced to reflect current flows, which are significantly less than the original flows for which the facility was designed. However, at least a minimum 6 months of winter storage must be retained (approximately $6.5 \mathrm{MG}$ at current flows). The water balance model indicates that reducing the existing volume of $24 \mathrm{MG}$ by $50 \%$ to $12 \mathrm{MG}$ should provide adequate storage for operations during both wet and dry years.

- The water balance model indicates that during a "wet" year $10 \mathrm{MG}$ would need to be discharged to land application with 7.7 MG during a "dry" year. However, these annual volumes are still well below the $37 \mathrm{MG}$ per year allowed by the facility's existing wastewater reuse permit.

Impacts to treatment effectiveness would need to be addressed if Cell 3 is eliminated. The existing reuse permit from DEQ lists Cell 3 as a "polishing lagoon." DEQ may require engineering justification for eliminating this cell to confirm that treatment goals will still be achieved prior to reuse. Without accounting for mixing inefficiencies, $12 \mathrm{MG}$ in Cell 2 would provide up to 340 days of detention time at current flows, which is still much more than necessary for facultative treatment. Therefore, if Cell 3 is eliminated and the size of Cell 2 is reduced, any impact to treatment from the reduction in overall detention time should still be insignificant. To implement this alternative, the following improvements would be needed:

- Abandon Cell 3 in accordance with INL requirements and an IDEQ-approved closure plan meeting the requirements of IDAPA 58.01.16.493.10. Abandonment would likely include removal and proper disposal of accumulated solids, the embankment liner, piping, and structures and smooth grading of the site.

- Reconfigure the piping and valving to allow conveyance of effluent directly from Cell 2 to the effluent irrigation pump station wet well.

- Remove and dispose of accumulated biosolids in accordance with a sludge management plan approved by the state and following EPA 40 CFR 503 rules. A CERCLA evaluation would likely be needed to assess whether disposal or land application can be used.

- Install new dikes across the center of Cell 2 and as needed to provide the reduced storage volume.

- Reconfigure the lagoon bottoms of Cells 1 and 2 to provide a bottom slope. Replacing the entire liner system will require removal of other unsuitable materials such as riprap and clay and reconstruction of the lagoon bottom to provide a suitable base for the new liner. While these disturbances are occurring, it is recommended to reconfigure the bottom of the cell to allow any gas that is generated under the new liner to migrate to the lagoon perimeter where it can safely escape. Gas can be generated by decomposing organic matter present in the native soils or from wastewater collecting under the liner from leaks.

- Install a new geosynthetic lining system and perform new seepage testing to verify compliance with DEQ's allowable seepage limit for new lagoons. 


\subsection{Selection of Preferred Alternative}

\subsubsection{Engineer's Opinions of Probable Cost}

Cost is an important consideration in the comparison of alternatives and selection of a preferred alternative for implementation. Engineer's opinions of probable cost beyond the scope of this study should be prepared for comparison of each alternative. The cost opinions should be prepared on a life cycle basis to account for not only construction costs but also operation and maintenance costs.

\subsubsection{Comparison of Alternatives}

A detailed comparison of the available alternatives beyond the scope of this study should be undertaken with consideration of a number of criteria such as life cycle cost, regulatory requirements, schedule, implementability, operation and maintenance requirements, and day-to-day reliability. 


\section{IMPLEMENTATION OF PREFERRED ALTERNATIVE 5.1 Regulatory Requirements}

IDEQ should be consulted to determine whether the implementation of any planned improvements would constitute a "material modification" to the facility and trigger a number of required submittals to IDEQ for review and approval (see IDAPA 58.01.16.410 through 425). These submittals may include:

- A facility planning study

- A preliminary engineering report (with prior IDEQ concurrence, this report may be incorporated into the facility planning study to satisfy this requirement)

- Construction drawings and specifications

- Record drawings and specifications

- Operation and maintenance manual.

Ongoing regulatory EPA/IDEQ requirements will be similar to those required for the existing facility. For alternatives that rely on continued use of the land application system, a wastewater reuse permit for discharge to land application will continue to be required.

Windblown dirt and settled solids from the wastewater will accumulate in the bottom of the lagoons. If solids accumulate in the lagoons to the point where they are using up excessive volume, they should be removed. The removed solids should be disposed of in accordance with a sludge management plan approved by the state and following EPA 40 CFR 503 rules. A CERCLA evaluation would likely be needed to assess whether disposal or land application can be used.

Post-construction and periodic seepage testing will continue to be needed in accordance with IDEQ requirements as required by IDAPA 58.01.16.493.02. Every 10 years, the seepage testing must be repeated.

If an existing lagoon is abandoned, it must be abandoned in accordance with an IDEQ-approved closure plan meeting the requirements of IDAPA 58.01.16.493.10. Abandonment would likely include removal and proper disposal of accumulated solids, the embankment liner, piping, and structures and smooth grading of the site.

\subsection{Summary of Implementation Steps}

To proceed with operation and monitoring of the existing system and eventual implementation of the preferred alternative, the following steps are recommended:

1. Continue monitoring and tracking flows at the influent lift station flow meter. Note any trends that show increasing or decreasing sanitary wastewater flow that may affect the conclusions in this study.

2. Confirm the reliability of the influent flow meter data. Verify that the check valves in the influent lift station are functioning properly. If necessary, the check valves should be repaired or replaced. A flow direction sensor could be installed on the force main to verify the direction of flow in the force main. An independent field check of the influent flow meter accuracy can be accomplished by timing how long it takes for a pump to pump down a given volume in the wet well and then comparing that average flow rate with the average flow rate indicated by the flow meter for that period.

3. Continue monitoring and tracking the addition of any supplemental water required to maintain a water cap in the lagoons. Note any trends that show an increasing seepage rate that may indicate a failing liner.

4. Perform an in-depth comparison of alternatives including consideration of life-cycle costs, and then select the preferred alternative and secure funding for its implementation. 
5. Initiate engineering tasks to prepare the documentation discussed in Section 5.1 to satisfy IDEQ requirements and to enable procurement of a contractor for construction of the necessary improvements.

6. Construct the necessary improvements.

7. Perform post-construction seepage testing of the upgraded lagoons in accordance with IDEQ requirements to verify compliance with allowable limits.

8. Prepare record drawings and update the operation and maintenance manual.

9. Close-out the project. 


\section{REFERENCES}

Cole, Mark, E-mail with Attachments Containing Daily STP Flow Readings for Permit Years 2010 2013, September 19, 2013.

IDAPA 58.01.16.010, “Wastewater Rules: Definitions,” Idaho Department of Environmental Quality, May 8, 2009.

IDAPA 58.01.16.410 through 425, "Facility and Design Standards for Municipal Wastewater Treatment or Disposal Facilities," Idaho Department of Environmental Quality, May 8, 2009.

IDAPA 58.01.16.493.02, "Facility and Design Standards for Municipal Wastewater Treatment or Disposal Facilities: Wastewater Lagoons," Idaho Department of Environmental Quality, May 8, 2009.

IDAPA 58.01.16.493.03, "Facility and Design Standards for Municipal Wastewater Treatment or Disposal Facilities: Wastewater Lagoons, Allowable Seepage Rates," Idaho Department of Environmental Quality, March 30, 2007.

IDAPA 58.01.16.493.09.c.i, "Facility and Design Standards for Municipal Wastewater Treatment or Disposal Facilities: Wastewater Lagoons," Idaho Department of Environmental Quality, May 8, 2009.

IDAPA 58.01.16.493.09.c.iii, "Facility and Design Standards for Municipal Wastewater Treatment or Disposal Facilities: Wastewater Lagoons," Idaho Department of Environmental Quality, March 30, 2007.

IDAPA 58.01.16.493.10, "Facility and Design Standards for Municipal Wastewater Treatment or Disposal Facilities: Wastewater Lagoons," Idaho Department of Environmental Quality, March 30, 2007.

INL, 1999, Wastewater Land Application Permit LA-000141 Renewal Information for the Central Facilities Area Sewage Treatment Plant, INEEL/EXT-98-01176, Lockheed Martin Idaho Technologies Company, February 1999.

INL, 2006, Central Facilities Area Sewage Treatment Lagoons Seepage Rate Test Report, INL/EXT-05-01011, Norm Stanley and Keith Hendrickson, Idaho National Laboratory Environmental Compliance, June 2006.

INL, 2006, 2005 Wastewater Land Application Site Performance Report for the Idaho National Laboratory Site's Central Facilities Area Sewage Treatment Plant, INL/EXT-06-12044, Idaho National Laboratory, February 2006.

INL, 2007, 2006 Wastewater Land Application Site Performance Report for the Idaho National Laboratory Site's Central Facilities Area Sewage Treatment Plant, INL/EXT-06-12044, Idaho National Laboratory Environmental Monitoring and Reporting, February 2007.

INL, 2008, 2007 Wastewater Land Application Site Performance Report for the Idaho National Laboratory Site's Central Facilities Area Sewage Treatment Plant, INL/EXT-08-13661, Idaho National Laboratory Environmental Monitoring and Reporting, February 2008.

INL, 2009, 2008 Wastewater Land Application Site Performance Report for the Idaho National Laboratory Site's Central Facilities Area Sewage Treatment Plant, INL/EXT-08-15209, Idaho National Laboratory Environmental Monitoring and Reporting, February 2009.

INL, 2010, 2009 Wastewater Land Application Site Performance Report for the Idaho National Laboratory Site's Central Facilities Area Sewage Treatment Plant, INL/EXT-10-17549, Idaho National Laboratory, February 2010. 
INL, 2011, 2010 Wastewater Land Application Site Performance Report for the Idaho National Laboratory Site's Central Facilities Area Sewage Treatment Plant, INL/EXT-11-20764, Idaho National Laboratory, February 2011.

INL, 2012, 2011 Wastewater Land Application Site Performance Report for the Idaho National Laboratory Site's Central Facilities Area Sewage Treatment Plant, INL/EXT-11-24269, Idaho National Laboratory, February 2012.

INL, 2013, 2012 Wastewater Land Application Site Performance Report for the Idaho National Laboratory Site's Central Facilities Area Sewage Treatment Plant, INL/EXT-12-27864, Idaho National Laboratory, February 2013.

Ischay, Chris, E-mail Regarding Current Staffing Levels at CFA, July 17, 2013.

J-U-B Engineers, Inc. Central Facilities Area Sewage Lagoon Evaluation (DRAFT), December 2013.

Tchobanoglous, George, Burton, Frank L., and Stensel, H. David, 2003, Wastewater Engineering: Treatment and Reuse, Metcalf \& Eddy, 4th ed., Revised, New York, New York, The McGraw-Hill Companies, Inc.

Western Regional Climate Center, "Monthly Average Pan Evaporation for Aberdeen Experiment Station," Period of Record 1914-2005, http://www.wrcc.dri.edu/htmlfiles/westevap.final.html\#IDAHO.

Western Regional Climate Center, "Monthly Total Precipitation for Idaho Falls 46 W Station," File Last Updated on April 4, 2014, http://www.wrcc.dri.edu/cgi-bin/cliMAIN.pl?id4460.

Western Regional Climate Center, "Period of Record Monthly Climate Summary for Idaho Falls46 W Station," Period of Record 4/1/1954 - 3/31/2013, http://www.wrcc.dri.edu/cgi-bin/cliMAIN.pl?id4460. 


\section{ATTACHMENTS}

The following items are attached to this report:

- Attachment A, Record Drawings for the CFA Sanitary Wastewater Lagoons

- The attached drawings are a partial set reflecting those sheets currently available from EDMS. 


\section{Attachment A}

\section{Record Drawings for the CFA STP}


Attachment A

Record Drawings for the CFA STP

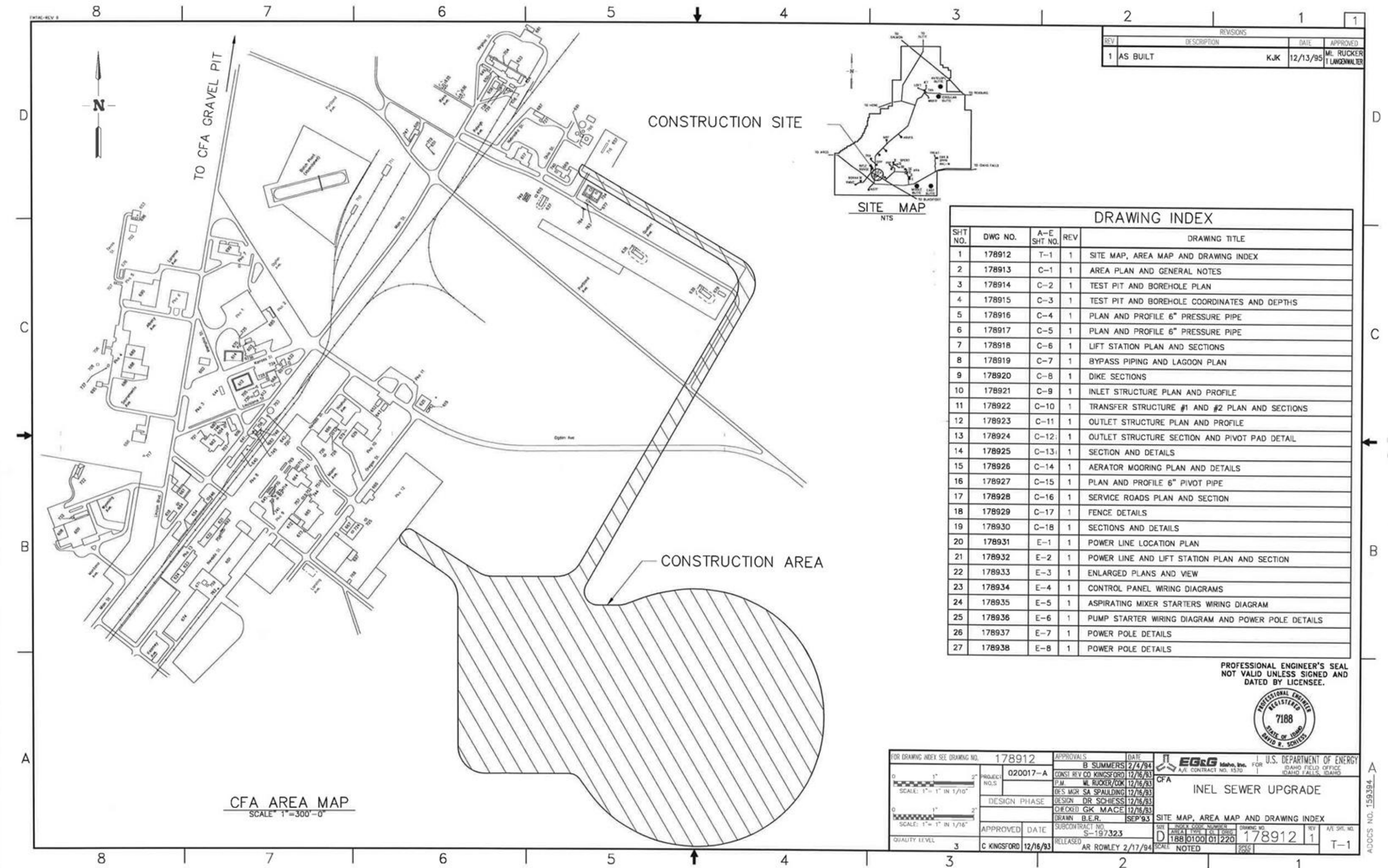




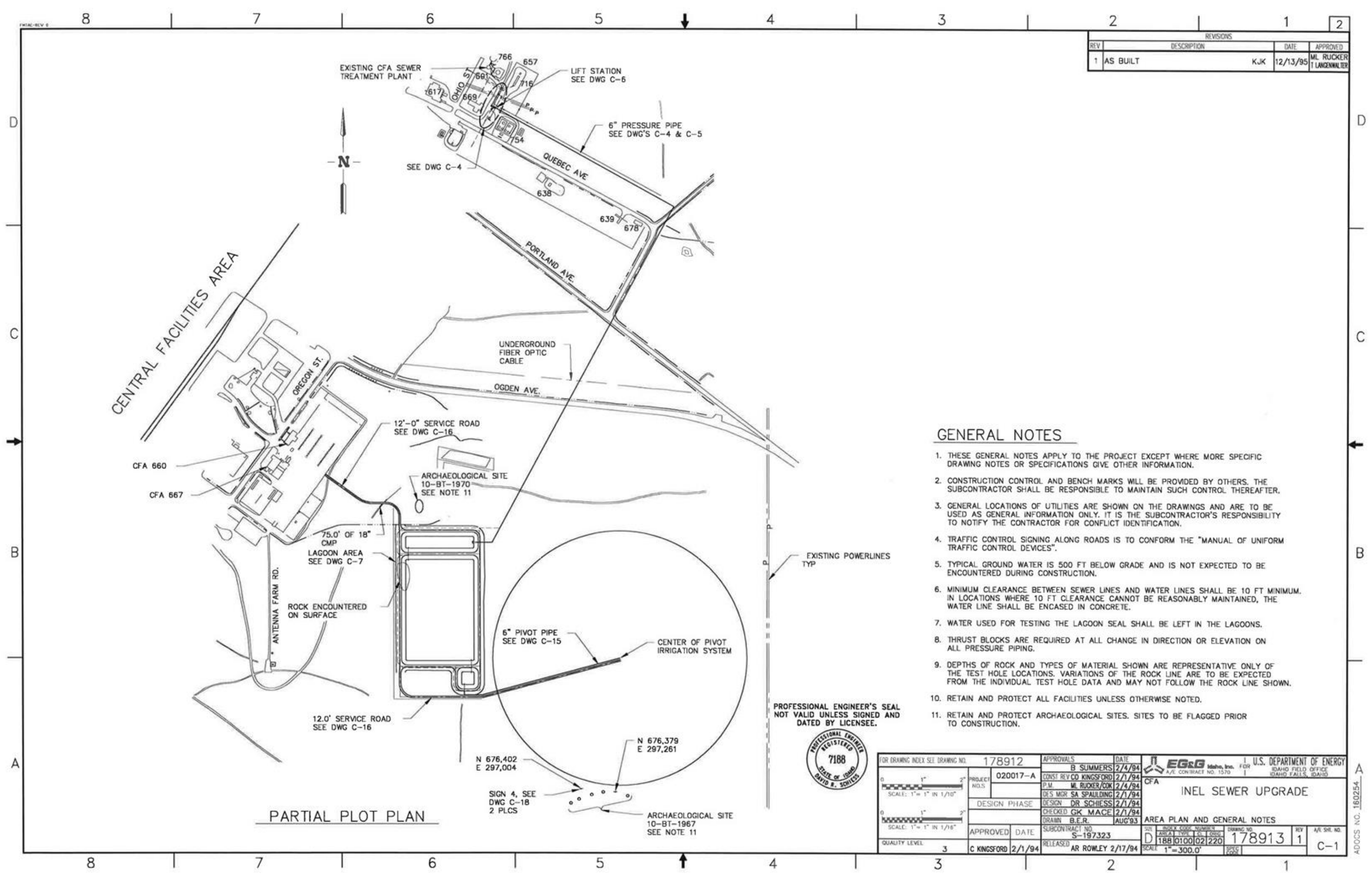




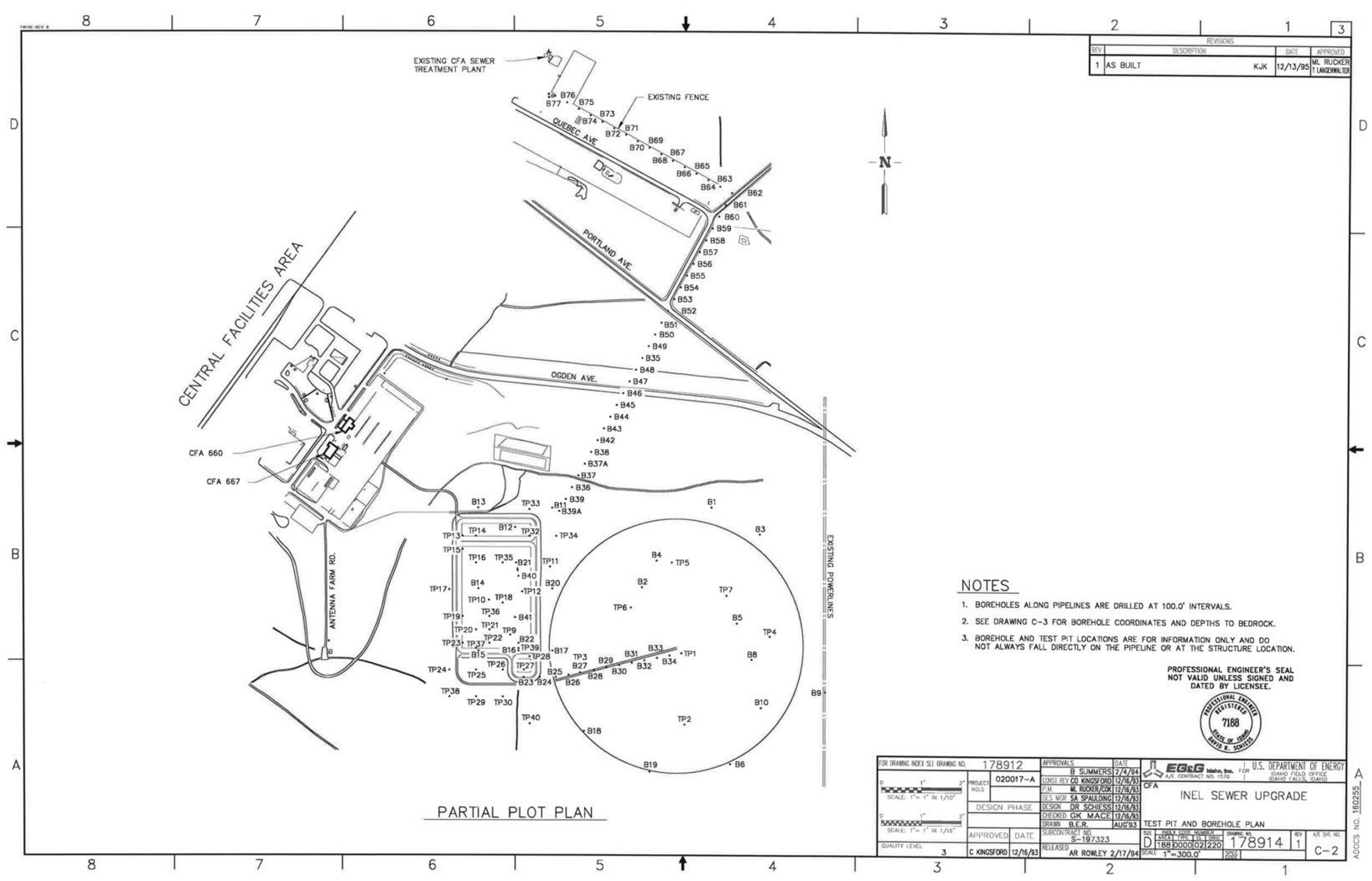




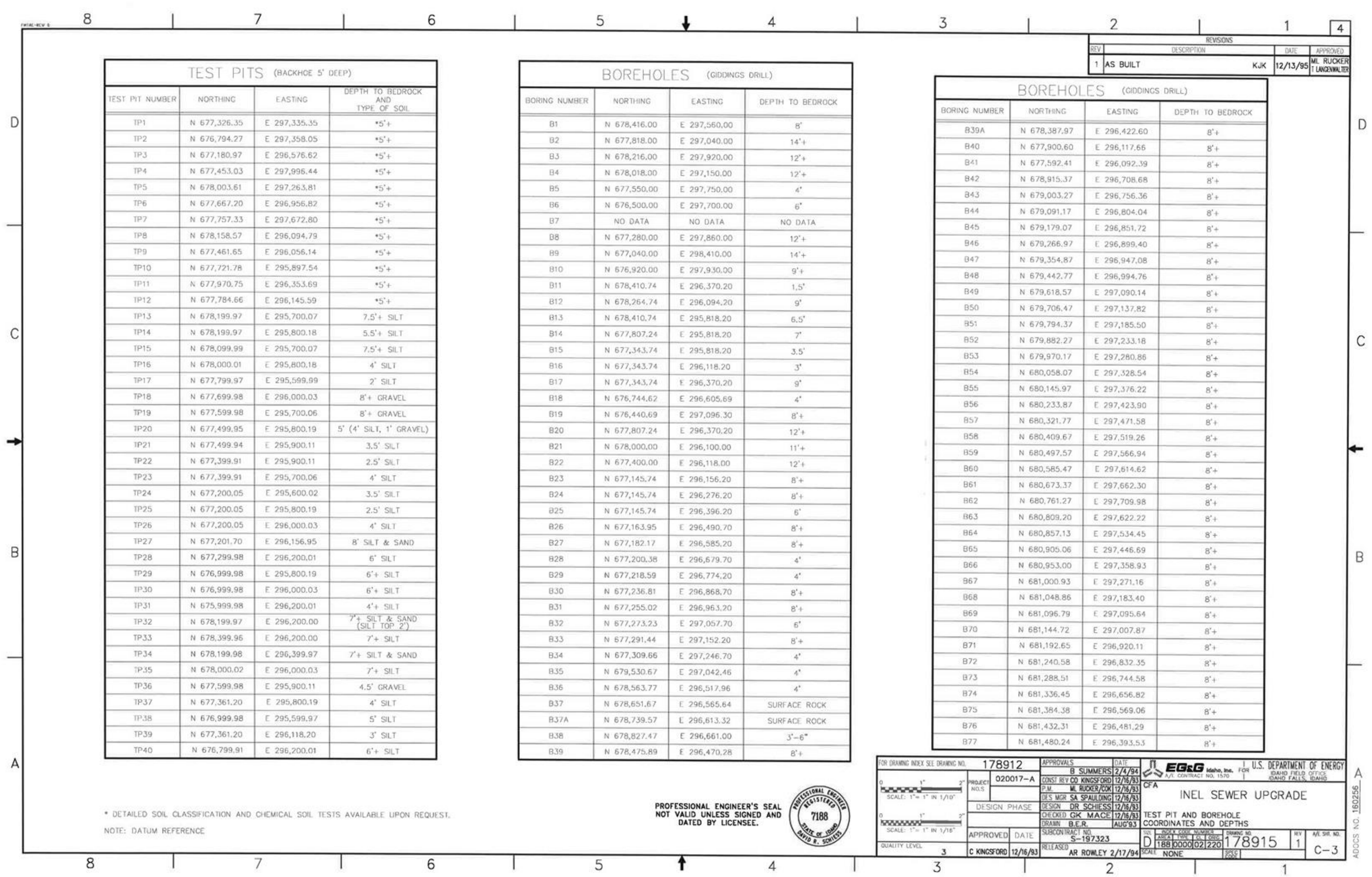




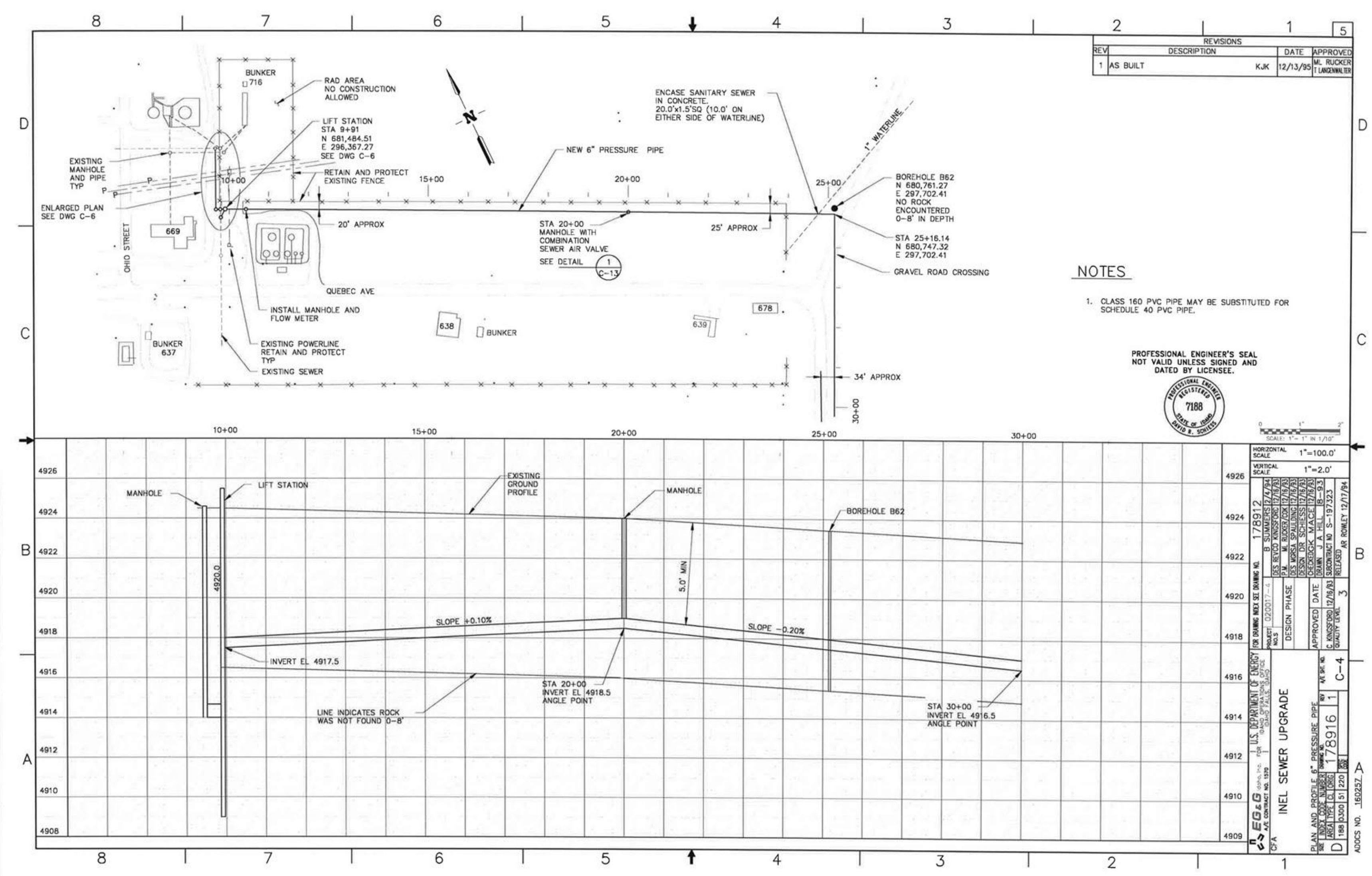




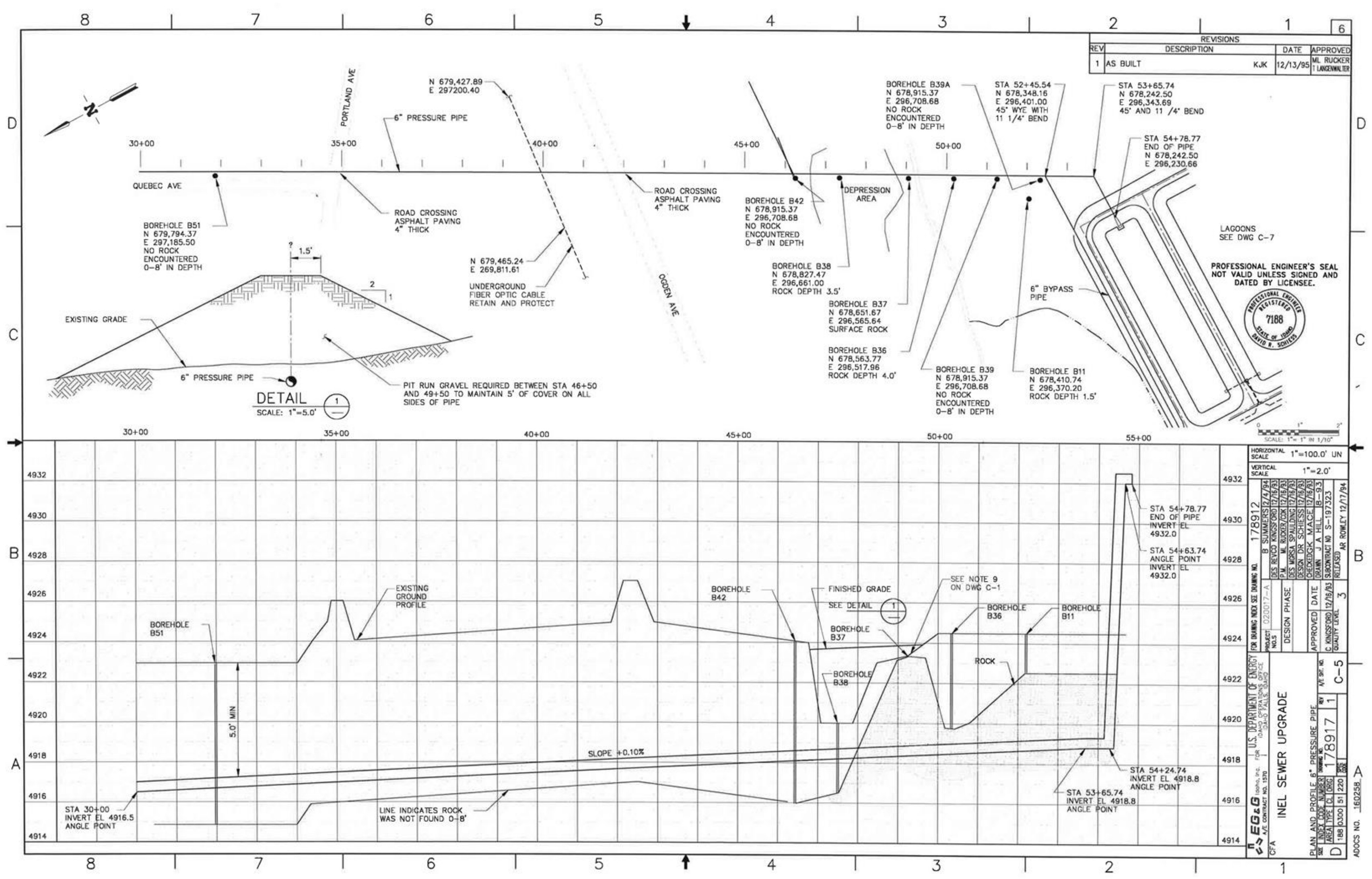




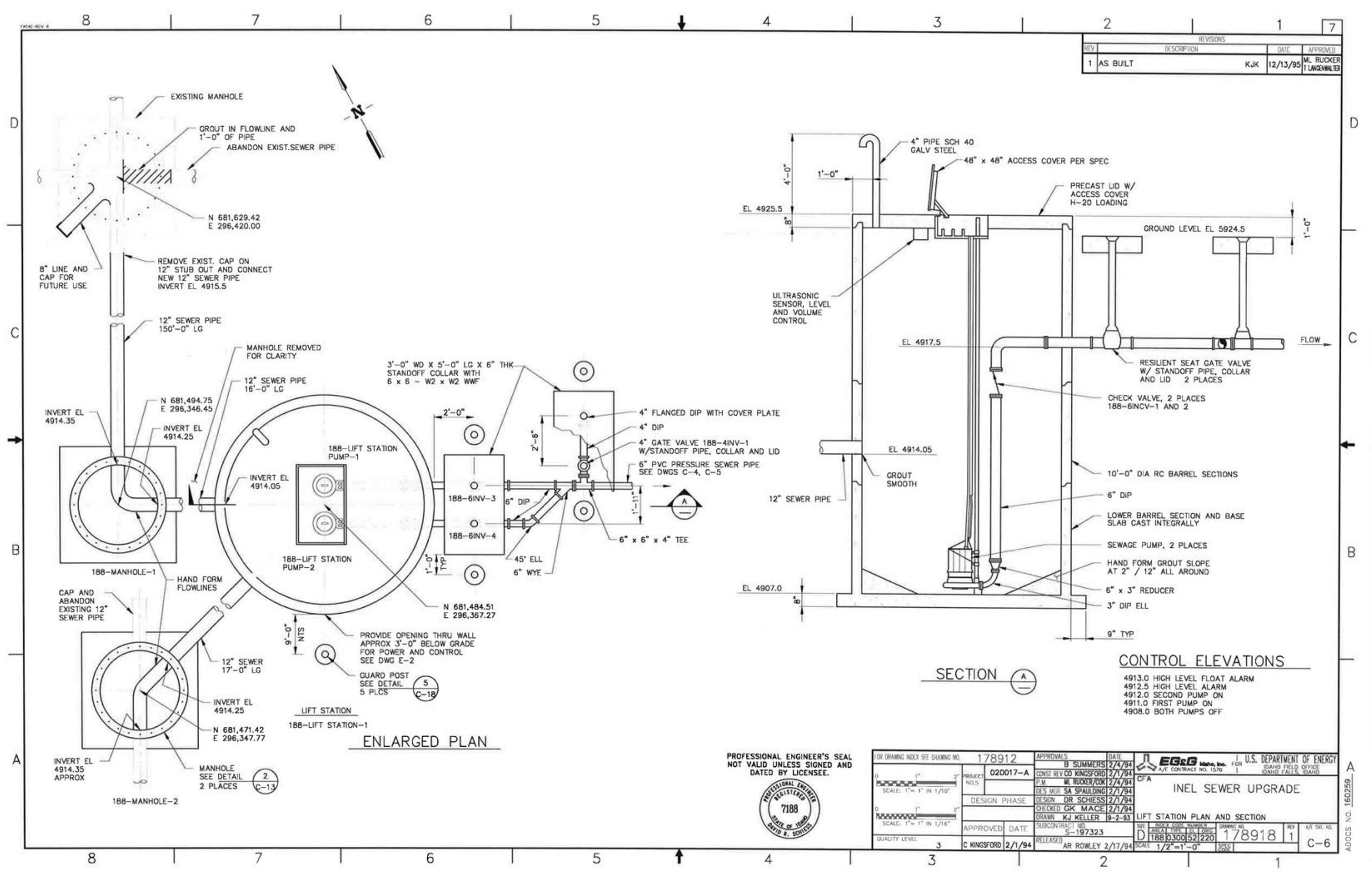




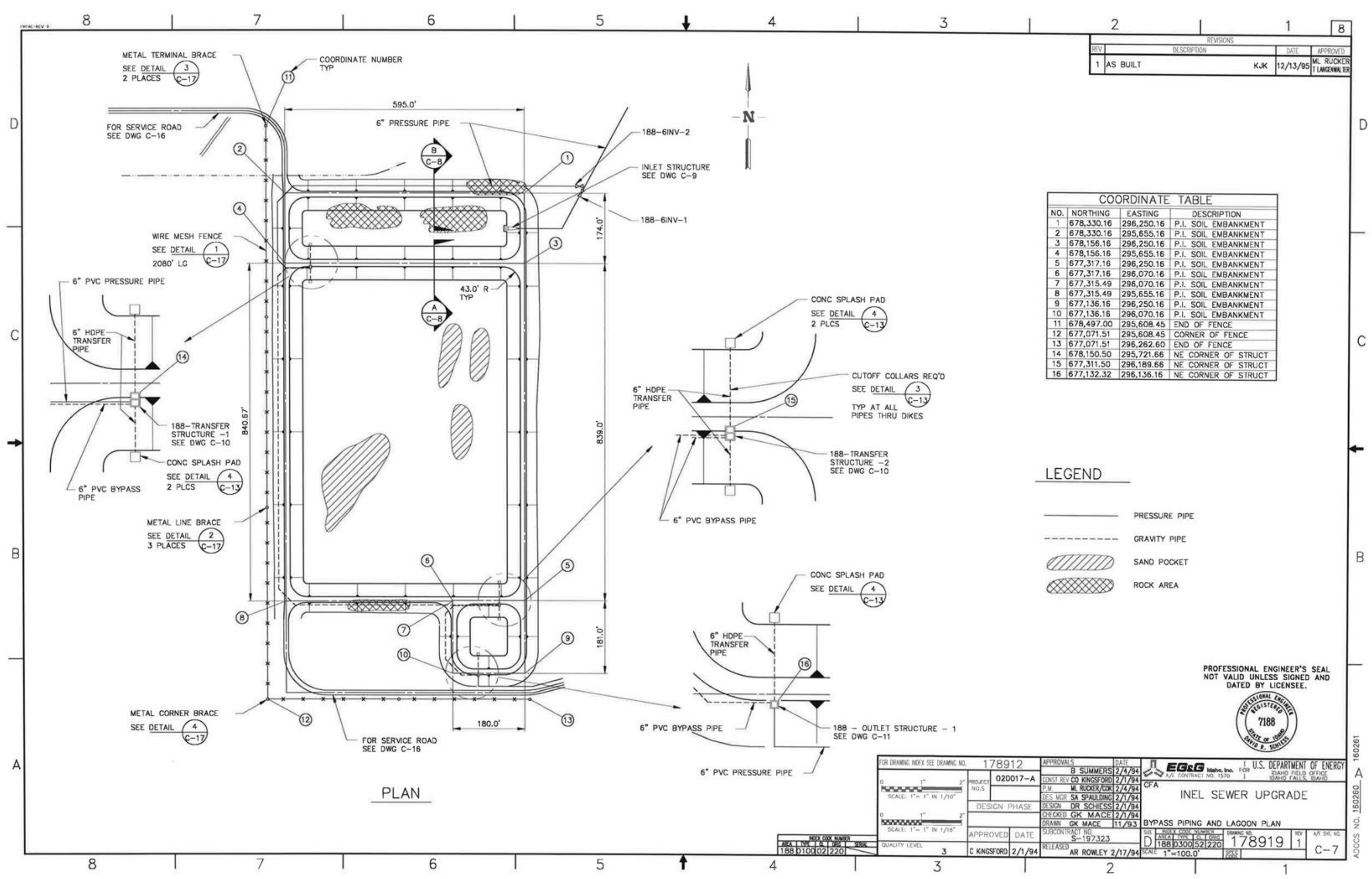




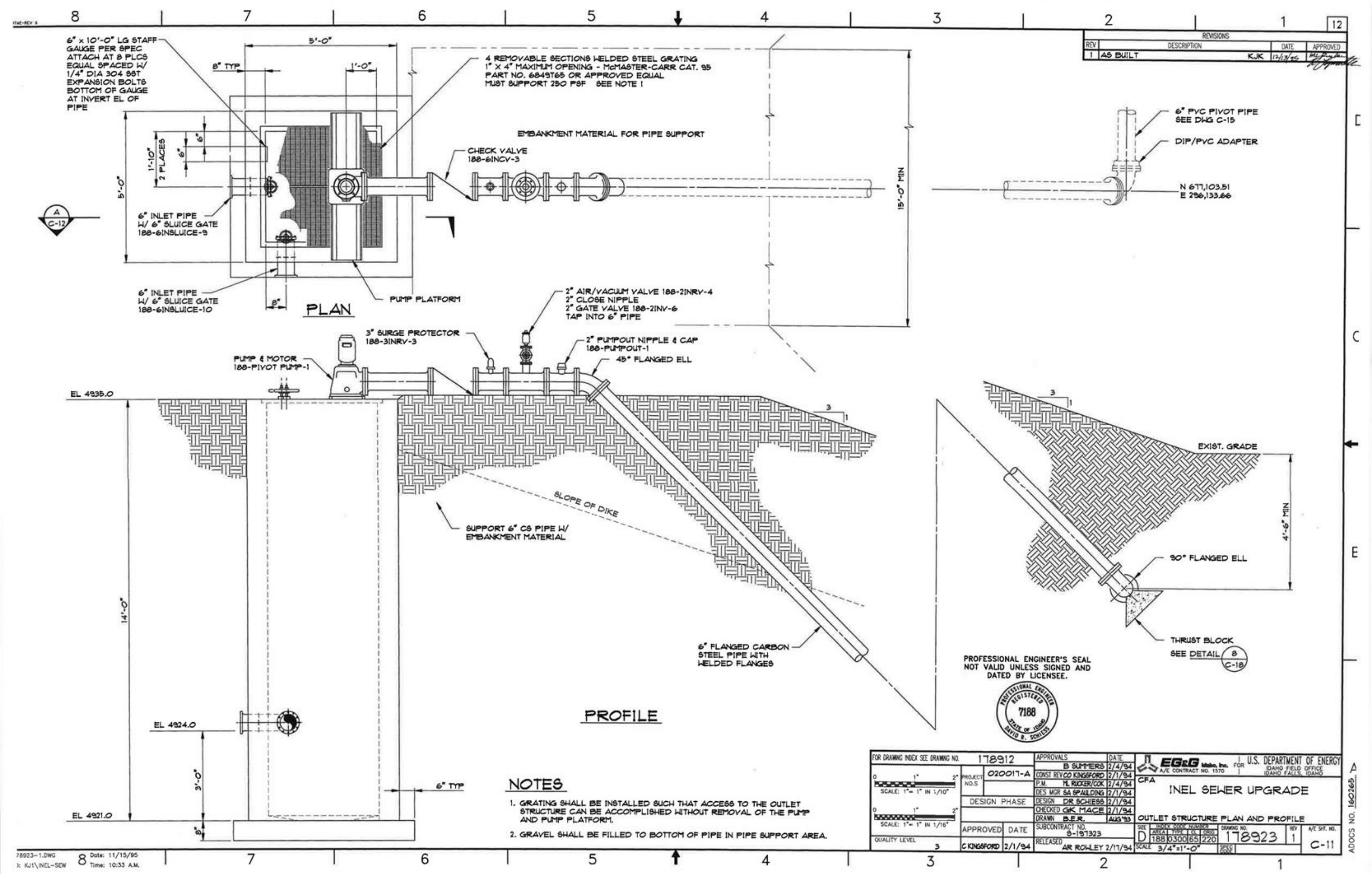

